\title{
Can Entrepreneurial Activity be Taught? Quasi-Experimental Evidence from Central America
}

\author{
Bailey Klinger and Matthias Schündeln
}

CID Working Paper No. 153

December 2007

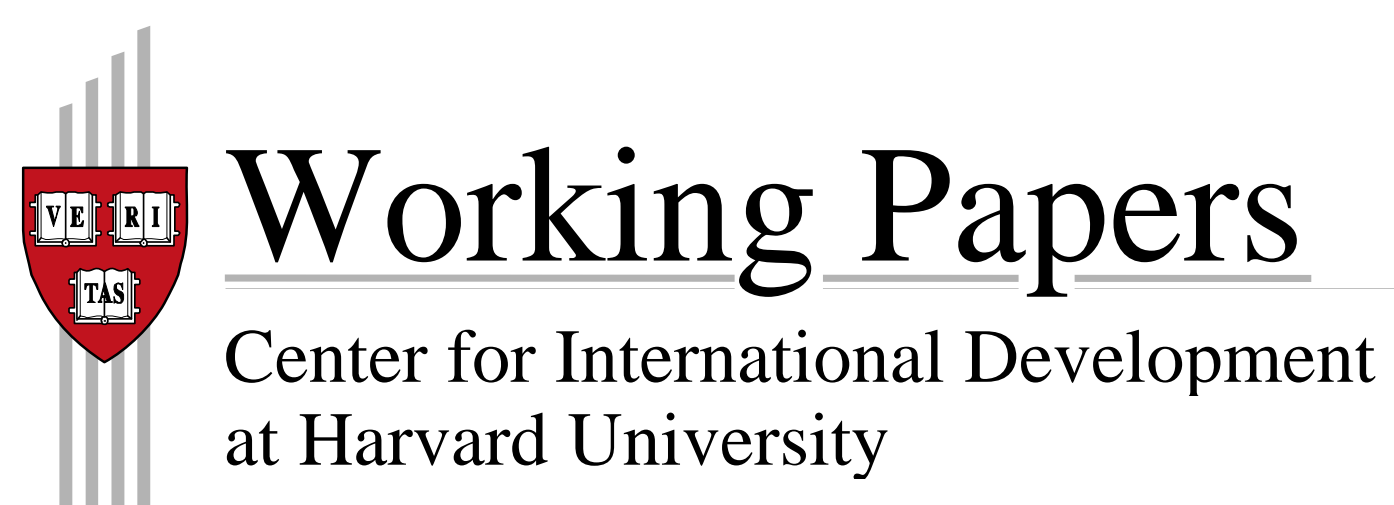




\title{
Can Entrepreneurial Activity be Taught? Quasi-Experimental Evidence from Central America
}

\author{
Bailey Klinger and Matthias Schündeln
}

\begin{abstract}
We study the effect of entrepreneurial training on enterprise outcomes, in particular whether business training for (potential) entrepreneurs of small- and medium scale enterprises can lead to an increase in the number of business start-ups or an expansion in the size of existing businesses. We study this question by analyzing the results of business training programs that an NGO held in Central America between 2002 and 2005. To deal with endogenous selection into the training program, we exploit the fact that a fixed number of applicants are taken into the training program based on a pre-training score, which creates a discontinuity around which we can compare accepted and rejected applicants and estimate the effect of training with a regression-discontinuity design. We find that receiving business training significantly increases the probability that an applicant to the workshop starts a business or expands an existing business. Thus, entrepreneurial activity such as starting and expanding businesses can be fostered by training. Exploiting the fact that in the last stage the most successful participants of the program receive substantial monetary prizes (between US\$ 6,000 and 15,000) we can also provide some experimental evidence that suggests the presence of financial constraints. Finally, we investigate gender differences, and find that females experience a much larger increase in the probability of starting a business if they win the monetary prize than men, suggesting financial constraints may be significantly larger for female entrepreneurs.
\end{abstract}

Keywords: entrepreneurship, business start-up, business training, human capital, financing constraints

JEL codes: L26, D21, J24, I21, O16 


\title{
Can Entrepreneurial Activity be Taught? Quasi-Experimental Evidence from Central America
}

\author{
Bailey Klinger \\ Kennedy School of Government \\ Harvard University
}

\author{
Matthias Schündeln* \\ Department of Economics \\ Harvard University
}

\begin{abstract}
We study the effect of entrepreneurial training on enterprise outcomes, in particular whether business training for (potential) entrepreneurs of small- and medium scale enterprises can lead to an increase in the number of business start-ups or an expansion in the size of existing businesses. We study this question by analyzing the results of business training programs that an NGO held in Central America between 2002 and 2005. To deal with endogenous selection into the training program, we exploit the fact that a fixed number of applicants are taken into the training program based on a pretraining score, which creates a discontinuity around which we can compare accepted and rejected applicants and estimate the effect of training with a regression-discontinuity design. We find that receiving business training significantly increases the probability that an applicant to the workshop starts a business or expands an existing business. Thus, entrepreneurial activity such as starting and expanding businesses can be fostered by training. Exploiting the fact that in the last stage the most successful participants of the program receive substantial monetary prizes (between US\$ 6,000 and 15,000) we can also provide some experimental evidence that suggests the presence of financial constraints. Finally, we investigate gender differences, and find that females experience a much larger increase in the probability of starting a business if they win the monetary prize than men, suggesting financial constraints may be significantly larger for female entrepreneurs.
\end{abstract}

\footnotetext{
${ }^{*}$ Corresponding author. Email: schuendeln@harvard.edu. We have received very useful comments from Guido Imbens, Nicola Fuchs-Schündeln and Dan Levy. We are grateful for research assistance from Michael Durán, and support from many individuals at TechnoServe, in particular Carolina Cely, Sandra Jetten, Steve Londner, and Bruce McNamer.
} 


\section{Introduction}

Entrepreneurial activity is important for development (e.g. Baumol 1968): Entrepreneurs implement new business ideas, or adopt profitable ideas from others to local circumstances to start new businesses, or they experiment with new materials and processes to expand their business. Inevitably some fail. A process of creative destruction, as described famously by Schumpeter (1911), leads to progress. ${ }^{1}$ In this paper we exploit the specifics of the training program that we study to implement a quasi-experimental research design (a regression discontinuity design) to study whether entrepreneurial activity can be taught, in particular whether business training can lead to increasing numbers of business started or expanded. We will study this question by analyzing the results of business training programs that an NGO held in Central America between 2002 and 2005. The program that we study attracts entrepreneurs with existing businesses of about 10 employees on average. Thus, unlike some other programs, this program targets businesses of a size beyond that of household enterprises.

It is now recognized that small and medium sized enterprises (SMEs) can play a significant role in the development process. However, current and potential entrepreneurs face many obstacles. Many of these obstacles are external and apply to all entrepreneurs in an economy, such as regulations, infrastructure, or macroeconomic uncertainty, and there is now a voluminous literature that studies the effect of these constraints on enterprise outcomes such as entry, exit and growth. However, many constraints are idiosyncratic to the potential entrepreneur, and these are less well studied. For example, individual entrepreneurs may not be willing to take risks. Some may simply not know how to navigate regulations and how to deal with other formal aspects of running a business, or how to deal with banks or other potential investors that would enable them to finance their new business or expand their existing business. Furthermore, a lack of skills may prevent them from calculating expected returns, which increases their uncertainty about potential outcomes beyond the uncertainty that is inherent in almost all entrepreneurial activity. "Entrepreneurial spirit" appears often to be seen as inherent in individuals, yet even for those who possess this entrepreneurial drive, they may not actually start a business or expand an existing business because of the myriad of potential obstacles. However, the examples above show that some of the idiosyncratic obstacles could potentially be overcome through business-specific education of (potential) entrepreneurs. This

\footnotetext{
${ }^{1}$ More recently, at the micro-level, theories such as those in which learning-by-doing plays a key role (either focusing on firms, such as Jovanovich 1982, or household businesses, such as Foster and Rosenzweig 1993) also recognize the importance of individuals who take risks by entering markets and using technologies with uncertain outcomes. At the macro level, Hausman and Rodrik (2003) and Hidalgo et al. (2007) provide theoretical and empirical evidence that supports similar ideas.
} 
paper's goal is to investigate whether this is possible. In particular, we study the effect that a specific training program implemented by an NGO in a large number of countries has on entrepreneurial activity, namely on business start-up and business expansion. In addition, another feature of the program, the quasi-experimental injection of substantial amounts of capital into some businesses, also allows us to investigate whether entrepreneurs are financially constrained, and the extent to which financing constraints hinder investment. Finally, we also investigate whether the effect of training and financing varies by gender.

The immediate question that we are interested in for this project is: can existing business development support programs that focus on entrepreneurial training improve enterprise outcomes and contribute to SME growth in developing countries? Although this question will be studied in the context of one particular organization, this research goes beyond an evaluation of one particular program. This research will be able to shed some light on the larger questions of the role of the entrepreneur, in particular the entrepreneur's human capital, in enterprise development, and to what extent entrepreneurial ability is exogenous and inherent to a firm owner or to what extent and how it can be shaped by training.

We study the role of entrepreneurial training on enterprise formation and enterprise outcomes in the context of business training programs run by the NGO TechnoServe. TechnoServe supports SMEs in the form of the so-called "Business Plan Competitions", which are intended to help individuals who are interested in setting up a new business to gain the necessary skills, and to help existing small and medium-scale entrepreneurs who wish to significantly expand their businesses improve their skills and entrepreneurial abilities. TechnoServe runs these training programs in several countries in Central America and Sub-Saharan Africa. We study the results of past competitions in El Salvador, Nicaragua, and Guatemala that took place between 2002 and 2005.

In each competition, there is first a preliminary screening process. A fixed number of applicants are selected for the program, which then receive the training. At the end of this phase, applicants submit a first draft of their business plan. Based upon a review by a small panel of "judges", a smaller group is selected to continue to the final phase, where they receive additional support and business development services to complete their business plan. The finalized plans are then again evaluated by "judges", and a fixed number of the top plans receive a financial prize of between $\$ 6,000$ and $\$ 15,000$ (depending on country and year), receipt of which is conditional on investment in the business, plus some additional business development services.

Existing evaluations of similar programs in the context of developing countries cannot 
answer the key question that is at the core of any program evaluation: How would a program participant have done in the absence of the program? In the specific case of the training workshop this means: how would the entrepreneur have done if he or she had not gone through the training workshop? The usual approaches of finding comparison groups to which program participants are compared are based on observable characteristics. The problem with these approaches is that we can expect a self-selection of entrepreneurs into any given program based on unobservable characteristics, which leads to biased estimates of treatment effects if these same characteristics also determine the future success and selection is not taken into account in the research design.

To overcome this problem, we take advantage of one particular feature of the program under study. Applicants have to undergo a standardized evaluation process in which a score is determined that is supposed to characterize the potential entrepreneurial ability of an applicant. Based on this score, the applicants are either accepted to the workshop (if their score falls above a cutoff) or rejected. This feature can be used to study the effect of program participation on outcomes based on a regression discontinuity design, by comparing rejected and accepted applicants.

Our findings indicate that the program is successful in promoting entrepreneurial activity. We find economically important and statistically significant changes in the probability that individuals open a new business or expand an existing business that are due to participation in the full training program. Looking at the different stages of the program, we find that the first round seminar-based training seems to affect expansion of businesses more than launching of new businesses. On the other hand, the second round, in which the business plan is developed more fully with more one-on-one assistance, affects more the launching of businesses. Similarly, the last round treatment, which is the receipt of prize money, has significant effects on launching, but smaller and less significant effects on expansion of businesses.

Finally, we investigate the role of gender, and find that females experience a much larger increase in the probability of starting a business if they win the monetary prize than men. This is strong evidence that financial constraints are significantly larger for female entrepreneurs.

The research is of immediate practical relevance. The development community is increasingly focusing on promoting Private Sector Development, recognizing that entrepreneurship is a key building block of sustained poverty-reducing economic growth. Philanthropic foundations, multilateral institutions, national governments, and non-governmental organizations are channeling large amounts of funds every year towards Private Sector Development programs that provide developing country entrepreneurs training, peer support networks, pro bono pro- 
fessional services, and finance. ${ }^{2}$ Yet, most of this work is performed with little knowledge of what works in scalable enterprise-based solutions to poverty, and is not targeted based on empirical evidence.

There is an emerging body of research into the characteristics of thriving entrepreneurs in developing countries. Recent examples of particular note are studies examining the personal, psychological, and sociological traits of entrepreneurs in Russia, China, Brazil, India, and Nigeria (Djankov et al. 2005 and 2006). However, we are only aware of one academic study that rigorously investigates the causal effect of entrepreneurial training on business outcomes. Karlan and Valdivia (2006) study the effect that business training has on participants in microfinance groups. However, the training aspect of the microfinance groups they study is relatively small and not the focus of their biweekly meetings. In addition, the majority of entrepreneurs in their study were micro-entrepreneurs. Other existing studies of entrepreneurial training, cited in Leibenstein (1987), have very small sample sizes (between 14 and 76 individuals received training).

Regarding financial constraints of small and medium enterprises, a recent experimental study by de Mel, McKenzie and Woodruff (2006) is of particular relevance. These authors estimate the returns to investment in Sri Lankan enterprises and conclude that financing constraints for small entrepreneurs are severe. Relatedly, McKenzie and Woodruff (2006) study small entrepreneurs in Mexico and find large (15\% per month) returns to capital in microenterprises. Schündeln (2007) presents evidence for the existence of financing constraints in small and medium enterprises in a large number of developing countries. ${ }^{3}$

The paper proceeds as follows. We first provide background on the program that we study and the data that we use. We then investigate whether the discontinuity in program participation that we wish to exploit holds. After that, we introduce the regression-discontinuity design in the context of our application, and then, as a first approach to the question at hand, look at reduced form/graphical results to check whether applicant characteristics and results

\footnotetext{
${ }^{2}$ Other prominent programs of this type are run by the United Nations Conference on Trade and Development (UNCTAD), the ILO and a number of NGOs such as Enablis and Endeavor. The one program with the biggest scope may be the one run by UNCTAD: UNCTAD supports SMEs in the form of the so-called "Empretec" enterprise development programs. The scope of the Empretec program, which has at its core a 2 week training workshop, is large. So far it has been implemented in at least 27 countries and has run workshops that have trained more than 70,000 current and aspiring entrepreneurs. Importantly, one of the TechnoServe business plan competitions actually uses the Empretec training program. The TechnoServe business plan competitions themselves are being scaled up significantly, with a host of competitions being rolled out throughout Africa, Central America, and South America.

${ }^{3}$ In a structural framework Schündeln (2006) quantifies the costs of financing constraints of small enterprises in Ghana and estimates that firm owners could roughly double their consumption in the absence of financing constraints.
} 
of interest are smooth around the discontinuity before the program and discontinuous after the program. Section 5 then presents the main results, as well as robustness checks. In that section we also discuss the role of gender. The final section concludes.

\section{The TechnoServe Business Plan Competitions}

This section provides some more detail about the business plan competitions that TechnoServe runs. An even more detailed description is given in the appendix. TechnoServe is an NGO founded in 1968, whose primary mission is to promote private enterprise as a solution to rural poverty. In the 1990s, the organization's focus expanded to promote entrepreneurship and competitiveness at the national level, and in 2002 in El Salvador, the organization developed and launched a Business Plan Competition to promote entrepreneurship. New competitions were quickly launched throughout Central America, and recently in Africa. These competitions provide training to both nascent entrepreneurs seeking to start a new business as well as to entrepreneurs with existing businesses that hope to undertake a significant expansion into a new product or market. Winners of the competition receive a financial award as seed capital for their business.

The competitions function as follows. The first phase consists of the organization and its local partners publicizing the competition and collecting applications. Applicants give basic personal information as well as a summary of their business idea. The competitions are usually subdivided into sectors. For example, some competitions divide applicants up into agroindustry, light manufacturing, and tourism, whereas others include sectors for womenowned businesses or rural businesses. Each application is scored, and the top applicants in each sector are accepted into the program.

It is important to note that the number of applicants that are admitted into the program, and the number of participants that subsequently progress to each stage, is fixed before the competition begins. This creates an exogenous cutoff which we will exploit to evaluate the program. It is also important to note that the scoring at the conclusion of phases 1, 2 and 3 is performed using standardized guidelines, but the panel of judges is often different for different sectors. Therefore, the numerical scores may not be strictly comparable across sectors, years and countries, and for this reason we standardize scores at the country-year-sector level (see the data section below).

The accepted applicants are admitted into phase 2, which consists of an entrepreneurial training program (the "training stage 1"). In the case of El Salvador, this training is provided first by the UN's EMPRETEC program over seven working days, which focuses on 
developing both technical business skills and 'core entrepreneurial behaviors' (for details see the appendix), followed by a TechnoServe workshop on business plan preparation. In the other countries, TechnoServe provides the entire training program, in three to four workshops covering such topics as entrepreneurial orientation and attitudes, strategic planning, financial projections, marketing, and how to write a business plan. This stage also provides countryspecific information on starting a business, such as the relevant government departments and programs, different legal forms, and potential sources of capital. The participants then must prepare a formal business plan, which is submitted in writing and judged by a panel.

The top scoring business plans at the conclusion of phase 2 ("training stage 1") proceed to phase 3 ("training stage 2 "), in which the participants further refine their business plans and receive more one-on-one assistance with mentors and consultants. These refined plans are then presented to a jury, which gives each plan a detailed score. The top scoring business plans receive a monetary reward of approximately US $\$ 9,000$ (between US $\$ 6,000$ and US $\$ 15,000)^{4}$ that is to be invested in a business. TechnoServe controls the disbursement to suppliers or pays directly for capital expenses to ensure the funds are invested in the proposed business.

This set-up is therefore a multi-phased competition where the participants are scored at each phase and an exogenous cutoff is used to determine who proceeds to the subsequent phase. This allows for a more robust impact evaluation than programs where the cutoffs are often endogenous. The following timeline summarizes the key parts of the program we study and introduces the nomenclature used below.

\begin{tabular}{llll}
\hline phase & condition & activity & $\begin{array}{l}\text { score at } \\
\text { end of phase }\end{array}$ \\
\hline phase 1 & none, all can apply & application & score $1(S 1)$ \\
phase 2 & if score 1 is above a cutoff & training ("training stage 1", $T)$ & score $2(S 2)$ \\
phase 3 & if score 2 is above a cutoff & $\begin{array}{l}\text { additional training ("training stage 2", } T 2) ; \\
\text { finalizing a business plan }\end{array}$ & score $3(S 3)$ \\
& & $\begin{array}{l}\text { winner of competition }(W) ; \\
\text { final stage }\end{array}$ & if score 3 is among the highest of a prize money \\
& & to be invested in a business & \\
& &
\end{tabular}

Table 1: Timeline and nomenclature

\footnotetext{
${ }^{4}$ The exact amounts and number of prizes handed out in our data is as follows: El Salvador 2002: 4 prizes of US $\$ 15,000$, El Salvador 2003: 5 prizes of US $\$ 12,000$, El Salvador 2005: 2 prizes of US $\$ 6,000$, Guatemala 2005: 11 prizes of US $\$ 10,000$, Nicaragua 2004: 9 prizes of US $\$ 10,000$, Nicaragua 2005: 6 prizes of US $\$ 10,000$.
} 


\section{Data}

As part of its monitoring and evaluation efforts, TechnoServe attempts to survey all competition participants who were accepted into phase 2, about one year after the competition. They determine whether or not the participant launched the new business or carried out the expansion that they proposed in the competition. TechnoServe also asks for sales and employment figures for the business. The data from these surveys was provided to the authors by TechnoServe.

Importantly, TechnoServe did not survey rejected applicants. Therefore, we collected additional, comparable data for observations below the phase 1 cutoff. In addition, we followed-up with competition participants who were accepted in to the program but that TechnoServe was not able to reach in their own follow-up surveys to further complete the dataset.

In addition to outcomes data, for each participant we have their status prior to entering the program, which is available from the application forms that each individual submitted: whether or not they were already operating a business, and if so, approximate numbers for employees and sales. Finally, we have demographic information from the sign-up sheets, such as age and gender, as well as scores for each of the phases before the participants were cut from the competition.

It is important to note that the businesses that we study are of a size well beyond household enterprises, which are somewhat more studied. The mean number of employees of businesses after the program is about 10 .

We study business plan competitions in three different countries (El Salvador, Guatemala and Nicaragua) over four years (with two competitions in Nicaragua and three in El Salvador), which had between 38 and 163 participants that were trained in at least one stage. We use a sample of 655 of accepted and rejected applicants to these entrepreneurial training workshops, 377 of these received at least some training and 278 were rejected applicants who did not receive any training.

Unfortunately, we have complete data on business size (employment and sales) only for businesses before the program. After the program we have this information only if the business is a new start-up or if it significantly expanded its business. Therefore, our analysis will focus on the variables that summarize the key goal of the business plan competitions, namely that individuals become more entrepreneurial, i.e. we focus on starting a business or significantly expanding a business (which are both measured as binary variables). These also have the advantage that they are less prone to measurement error than outcomes such as profits (see de $\mathrm{Mel}$ et al. 2007a). 


\subsection{Did the discontinuity hold?}

Our methodology presumes a discontinuity in program participation. Therefore, before proceeding, we first investigate whether program participation was following a strict rule, i.e. whether there is indeed a discontinuity in program participation based on the score that an individual received in the application process. We standardize the scores of phase 1, 2 and 3 by subtracting the cutoff and dividing by the standard deviation of each individual competition, such that the cutoff is always equal to 0 and scores have the same variance. In figure 1 we first plot the kernel density of phase 1 scores. This figure shows that scores just above the cut-off are not more likely, thus, there is no evidence that individuals were moved up so that they just fall above a threshold score. ${ }^{5}$

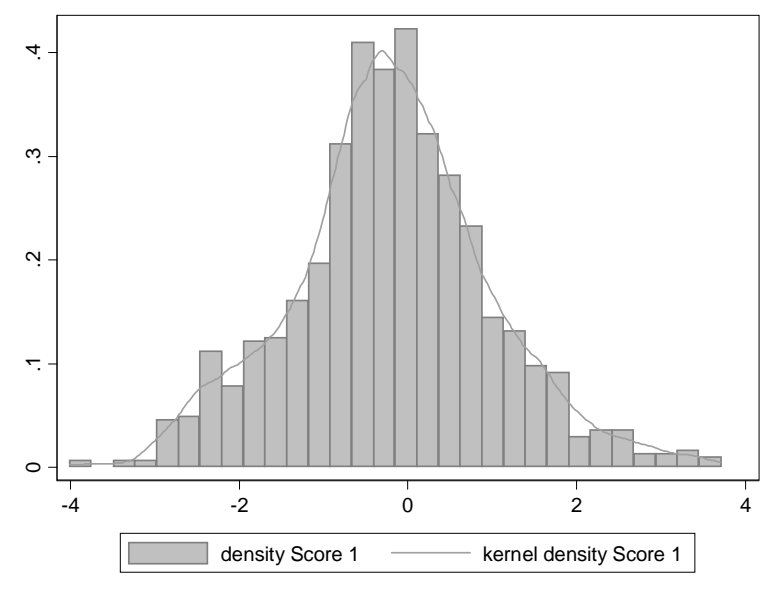

Figure 1: Is there a discontinuity in first-stage scores around the cutoff?

\footnotetext{
${ }^{5}$ One could imagine that a central office sets a standard above which all those who achieve the standard are allowed into the training and a local office that then moves up scores, just lifting them above the threshold, so that many more individuals can participate.
} 
The second question is whether indeed individuals above a cut-off are more likely to be trained than those below the cut-off. To gain insights into this, consider the histograms in figure 2 (overlaid with kernel density estimates). On the left side we have individuals that were not trained, and on the right there are those that were trained. We clearly see that the cut-off was obeyed to almost perfectly. Thus, there is a significant discontinuity in the raw training data: Applicants below a threshold are much less likely (highly significant in regressions not shown) to enter the program than applicants above a threshold.

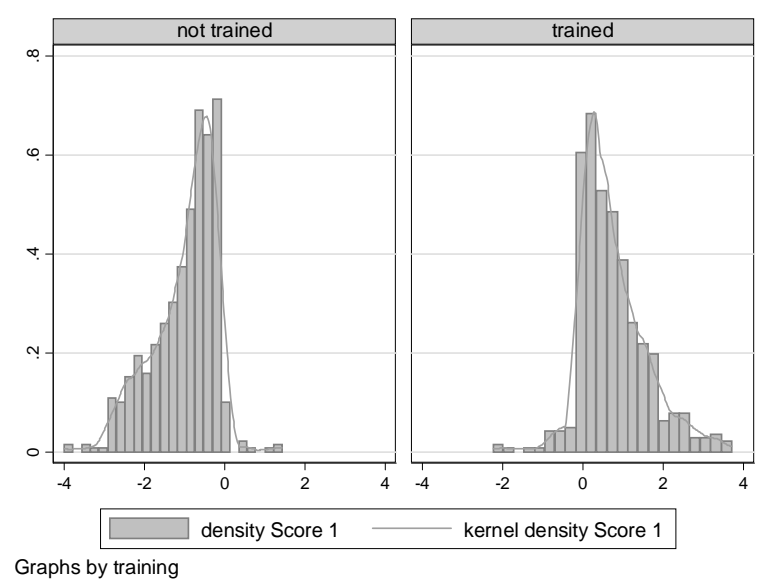

Figure 2: Is there a discontinuity in training participation? 
Similarly, we investigate whether the discontinuity exists at the stage where trained individuals potentially can progress to the second stage of training. Figure 3 shows that, again, there is a strong discontinuity around the cut-off. Nevertheless, a few individuals (namely 7) just below the cut-off were taken into the second training round of the program, and one above the cut-off is not participating in the next round of the training. It turns out that all these observations are from the competitions in El Salvador. For this and another reason explained below we also demonstrate in robustness checks that the main results do not change qualitatively when we consider only data from Guatemala and Nicaragua.

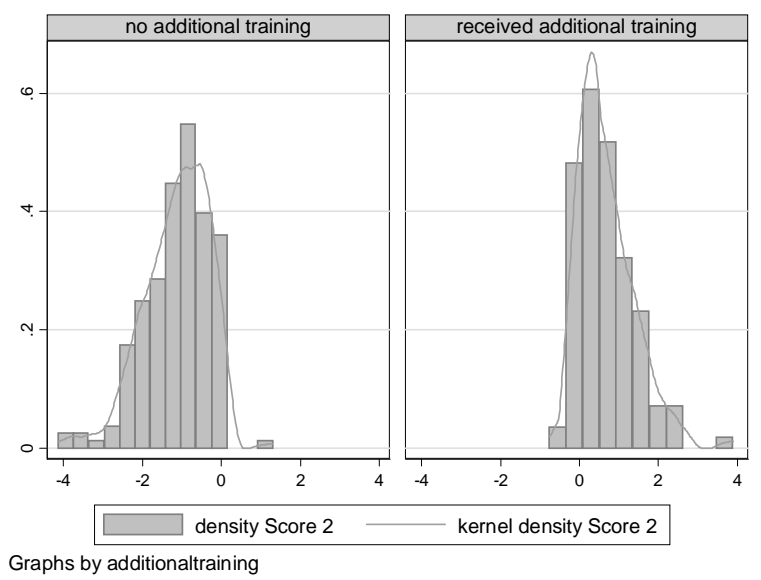

Figure 3: Is there a discontinuity in the transition from the first to the second training stage?

Finally, we investigate whether the discontinuity exists at the winner stage. It turns out that at the winner stage, the cutoff was strictly enforced, i.e. at this stage the discontinuity is sharp. This is no surprise given what is immediately at stake, namely prize money of at least US\$ 6,000 for the winners. So there is no concern about accepted applicants not taking the prize, and apparently there was also no one receiving a prize who did not make the cut-off. Prizes were awarded to individuals with the highest scores in the evaluation at the last stage of the competition. 


\section{Methodology: regression discontinuity design}

Our interest is in the causal effect of participation in the training program on outcomes such as business start-up or business expansion. To establish causality, we resort to a quasiexperimental approach, namely a regression discontinuity research design. ${ }^{6}$ Our setup is somewhat non-standard because it involves a number of sequential stages, with each involving a separate discontinuity that we will exploit. To illustrate the econometric approach, however, we will first discuss the standard setup with one discontinuity. Consider the following structural relationship between training participation and outcomes:

$$
y_{i}=\alpha+\gamma \cdot 1(\text { training participant })_{i}+\delta \bar{X}_{i}+u_{i}
$$

Here, 1(training participant) is an indicator variable that is equal to one if the individual participated in the training program, and $\gamma$ is the parameter of interest. $\bar{X}_{i}$ is a vector of observable characteristics. However, as is well known, the difficulty with getting at causality is that in non-experimental settings training participation, 1 (training participant), is most likely correlated with unobserved characteristics $u_{i}{ }^{7}$

The fact that applicants are assigned a score based on which program participation eligibility is determined can be exploited for a regression discontinuity design. We have demonstrated that indeed a significant discontinuity exists in the applicants' scores at the end of phase 1; applicants with a score above a certain cut-off have a significantly higher probability of getting into the program. For the purpose of this discussion, let applicant $i$ 's phase 1 score be $S 1$, and denote with $\overline{S 1}$ the cutoff score. We exploit this for identification of the effect of the training. Similarly, a discontinuity exists at the scores for the second and third round. We use these to estimate the effect of additional training, and the effect of the prize money that the "winners" of the business plan competitions receive.

\footnotetext{
${ }^{6}$ For a theoretical treatment see van der Klaauw et al. (2001). For other prominent examples of this approach, see for example, Angrist and Levy (1999), van der Klaauw (2002), Jacob and Lefgren (2004), or Ludwig and Miller (2007).

${ }^{7}$ For example, it is likely that individuals who are interested in a training program such as the one offered by TechnoServe have some ideas about a potential business that they are planning to start. So comparing individuals in the program with individuals from the general population in a simple OLS regression framework in which we regress business outcomes on a training-participation dummy variable would give biased estimates. In this particular example, we expect a positive correlation between $u_{i}$ and program participation, and OLS would overestimate the true effect of the program. However, one could also imagine that people enter the training workshop because they lack ideas, do not gain anything from the workshop and never start a business or never expand their business, even with training, while those who do have business ideas, and would also gain from the workshop, skip the workshop because they are busy starting-up or expanding their businesses. This would imply a negative correlation between unobservables and training participation and thus a downward bias on the OLS estimate. It follows that the direction of the bias is indetermined.
} 
Because we exploit discontinuities in which program participation is imperfectly predicted by the assignment variable (i.e. a so-called "fuzzy" regression discontinuity research design) as well as a discontinuity in which program participation is perfectly predicted by the assignment variable (in the final winning stage, i.e. here we have a "sharp" regression discontinuity research design), and also use different specifications in which we allow for different interaction effects of the treatment with the assignment variable, it is useful to introduce the underlying assumption for each of these approaches in turn.

In a regression discontinuity research design the general idea is that if for individuals around the cutoff unobservable characteristics do not vary discontinuously, then program participation can be thought of as essentially randomly assigned to individuals around the cutoff. This could be exploited by estimating the baseline regression discontinuity equation (using the discontinuity created by phase 1 score $S 1$ as an example to illustrate the approach):

$$
y_{i, a f t e r}=\alpha+\gamma \cdot 1\left(S 1_{i}>\overline{S 1}\right)+\delta \bar{X}_{i}+f\left(S 1_{i}\right)+u_{i}
$$

where $y_{i, a f t e r}$ is an outcome of interest for applicant $i, 1\left(S 1_{i}>\overline{S 1}\right)$ is an indicator function which is equal to one if applicant $i$ 's phase 1 score is above the cutoff for being admitted into the training program, $f\left(S 1_{i}\right)$ is a function in applicant $i$ 's phase 1 score, and $\bar{X}_{i}$ is a vector of other exogenous controls. ${ }^{8}$ The parameter $\gamma$ in this case would be an estimate of the average treatment effect for individuals close to the cutoff. $f\left(S 1_{i}\right)$ is included because the regression-discontinuity design relies on an assumption that holds only in the limit, and therefore in practical terms holds only in a small neighborhood around the cutoff. Especially if the variable that was used to assign treatment (here the score $S 1$ ) is related to outcomes, using all available observations and thus increasing the interval around the cutoff score that is used for estimation will likely introduce a bias in $\gamma$. Because we know the value of the variable $S 1$ that was used to assign treatment we can include this in our regression framework ${ }^{9}$, thus controlling for the effect of this variable, and increase the area around the cutoff from which we draw observations, thus increasing the number of observations available for estimation purposes.

If, additionally, the treatment effect varies with the variable used for selection, we need to interact $f\left(S 1_{i}\right)$ with $1\left(S 1_{i}>\overline{S 1}\right)$ to estimate

$$
y_{i, a f t e r}=\alpha+\gamma(\overline{S 1}) \cdot 1\left(S 1_{i}>\overline{S 1}\right)+\delta \bar{X}_{i}+f\left(S 1_{i}\right) \cdot 1\left(S 1_{i}>\overline{S 1}\right)+u_{i} .
$$

\footnotetext{
${ }^{8}$ The other controls serve to reduce the noise and thus to increase precision of the estimates, but they are not necessary for this approach to give consistent estimates.

${ }^{9}$ We need to make an assumption about the functional form in which this variables is related to outcomes.
} 
Note that in this case we can only identify $\gamma(\overline{S 1})$, the local treatment effect at $\overline{S 1}$.

The procedure described above relies on a "sharp" discontinuity, in which program participation is perfectly predicted by the program score, thus $1\left(S 1_{i}>\overline{S 1}\right)=1$ (training participant). However, more frequently there are stochastic elements in the assignment. Some individuals above the cutoff will not participate in the program, while some below will participate. We have shown above (in figures 2 and 3) that this is true for the present data. Reasons for this may be related to program officers or individuals; either way, the problem here is that the characteristics that determine whether the individual participates in the program or not are unobserved to the econometrician. This is what is termed a "fuzzy" regression discontinuity design. Here, the regression of interest is

$$
y_{i, a f t e r}=\alpha+\gamma \cdot T_{i}+\delta \bar{X}_{i}+f\left(S 1_{i}\right)+u_{i}
$$

where $\mathrm{T}$ is an indicator function that is 1 if an individual participated in the training, and zero otherwise. This is different from the setup above in the "sharp" discontinuity design, because there is no longer a one-to-one match between $T$ and $1\left(S 1_{i}>\overline{S 1}\right)$. However, unlike in the case where the score predicts perfectly the treatment, here unobservables are expected to play a role, introducing a correlation between $T$ and $u_{i}$. Thus, estimating equation 4 with OLS no longer gives consistent estimates. To deal with this, in a fuzzy regression discontinuity design the existence of the cutoff score can be exploited as an instrument for program participation. ${ }^{10}$

Alternatively, in case of a non-sharp discontinuity, one can simply use the indicator function $1\left(S 1_{i}>\overline{S 1}\right)$ directly, i.e. without estimating in a first stage the probability that an individual whose score falls above the cutoff actually participates in the program (as for example used in Ludwig and Miller 2007). This is an approach that we employ below to test for robustness of our results, the estimating equation is:

$$
y_{i, a f t e r}=\alpha+\gamma \cdot 1\left(S 1_{i}>\overline{S 1}\right)+\delta \bar{X}_{i}+f\left(S 1_{i}\right)+u_{i}
$$

which will give an estimate of the average intent-to-treat effect.

\footnotetext{
${ }^{10}$ In a first stage, program participation is predicted based on the value of the assignment variable (score $S 1)$ and an indicator whether the value of the assignment variable falls above the cutoff for program participation. To estimate the parameters of equation 4, the estimated participation probability from this first stage is then used in the second stage instead of the treatment indicator variable. If the assignment variable is assumed to enter with the same functional form in the first and the second stage, standard two-stage procedures (such as two-stage least squares) can be used for this. Similarly, in the case of treatment effects that vary with the value of the assignment variable, the parameters of an equation analogous to equation 3 can be estimated with an analogous instrumental variables strategy.
} 
In our setup there is one non-standard feature, though: the treatment is not homogenous, with treatment determined by a sequence of assignment variables (i.e. the scores assigned after three different phases of the training program). ${ }^{11}$ The treatment heterogeneity results from the fact that out of the set of trained individuals only a subset is selected based on further scores (score 2 and score 3 ) after the first round of training. It it important to keep this in mind when we interpret the results. Given our setup it is not possible to estimate the effect of training separately from the effect of the financial treatment. Instead, we identify three different treatment effects: (1) We first estimate the effect of being in the first training program; this includes some individuals who go on to the second stage of the training program and a few that eventually win the competition and receive a monetary prize. (2) We can then estimate the effect of the additional training, conditional on having been in the first training. (3) We can estimate the effect of winning the competition, conditional on having been in the first training and having participated in the second round of training. More formally, our baseline specifications are as follows:

$$
\begin{aligned}
& y_{i, a f t e r}=\alpha+\gamma(T) \cdot T_{i}+\delta \bar{X}_{i}+f\left(S 1_{i}\right)+u_{i} \\
& y_{i, a f t e r}=\alpha^{\prime}+\gamma\left(T 2, S 1_{i}>\overline{S 1}\right) \cdot T 2_{i}+\delta^{\prime} \bar{X}_{i}+f^{\prime}\left(S 2_{i}\right)+u_{i}^{\prime} \\
& y_{i, a f t e r}=\alpha^{\prime \prime}+\gamma\left(W, S 2_{i}>\overline{S 2}\right) \cdot W_{i}+\delta^{\prime \prime} \bar{X}_{i}+f^{\prime \prime}\left(S 3_{i}\right)+u_{i}^{\prime \prime}
\end{aligned}
$$

Here, $T$ denotes again training participation, while $T 2$ is an indicator that is equal to one if the individual participated in the second round of training, while $W$ is an indicator function that is equal to one if an individual is the winner of a monetary prize at the of the second round of training. Thus, $\gamma(T)$ is the average effect of the first training, $\gamma\left(T 2, S 1_{i}>\overline{S 1}\right)$ is the effect of the second part of the training workshop, conditional on having participated in the first part of the training, and $\gamma\left(W, S 2_{i}>\overline{S 2}\right)$ is the effect of winning the prize money at the end of the business plan competition, conditional on having participated in the first and second rounds of training.

We do have non-perfect discontinuities at $\overline{S 1}$ and $\overline{S 2}$, i.e. a "fuzzy" research design. Therefore, we need to instrument $T_{i}$ and $T 2_{i}$, which we do with the indicator variables $1\left(S 1_{i}>\right.$ $\overline{S 1})$ and $1\left(S 2_{i}>\overline{S 2}\right)$, respectively. However, we do have a sharp discontinuity in the last stage and therefore we do not need to instrument for $W$, the winning indicator.

We generally include linear and squared terms of the score variables S1, S2, and S3. We also run specifications in which we interact the functions $f\left(S 1_{i}\right), f^{\prime}\left(S 2_{i}\right)$ and $f^{\prime \prime}\left(S 3_{i}\right)$ with the

\footnotetext{
${ }^{11}$ Some other authors have dealt with non-homogenous treatments (e.g. different amounts of financial aid offers, as in van der Klaauw 2002), however, those are determined by only one assignment variable, and different cutoffs within this one variable determine the treatment amounts.
} 
indicator variables $T, T 2, W$, respectively, to allow for the effect of the various stages of the business plan competition to vary with the scores.

Our data allow us to study the following dimensions of enterprise outcomes: business started (if participant had previously no business), business expanded (if participant had pre-existing business), and a combined measure indicating whether an individual started or expanded a business.

\subsection{Are outcomes smooth around cut-off before the program?}

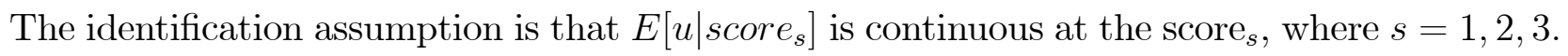
This implies that outcomes in the absence of an intervention are smooth around the cut-off. To support this assumption, we will first check outcomes before the individuals participated in the training program.

Consider the distribution of applicants with and without a business. First, simply eyeballing the histograms and kernel density plots in figure 4 we do not find a noticeable discontinuity in this outcome around the cutoff for score 1 (recall scores are rescaled such that the cutoffs are equal to 0$)$.

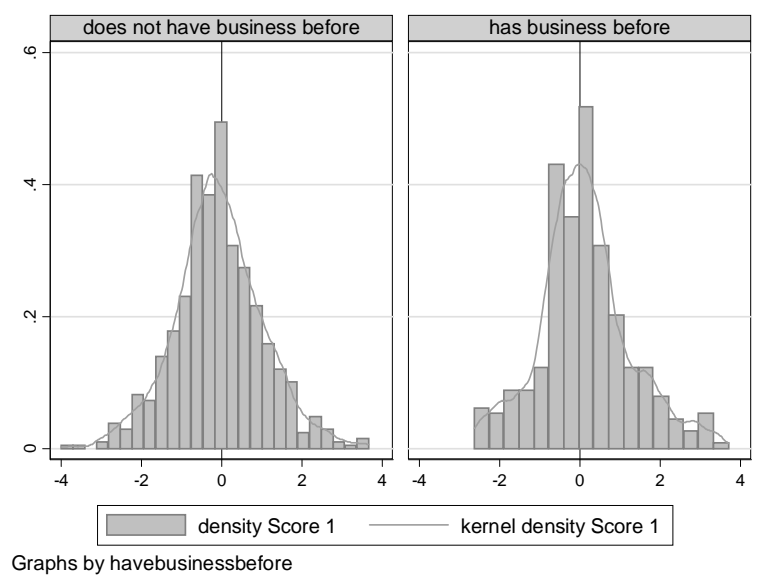

Figure 4: Is there a discontinuity in outcomes before the program?

An alternative way of looking at this is using a locally weighted regression of an indicator function that is 1 if an individual owned a business in the year before the program on the phase 1 score (figure 5). Again, the plot does not indicate a discontinuity around the cutoff score of 0 . On the other hand, this plot provides some evidence for the fact that phase 1 score may predict outcomes. Thus, it is important to control for the score itself, as indicated in equation 5. 
Finally, we can also analyze the question about a discontinuity before the program more formally. This is done through a regression of an indicator variable that is equal to one if an individual owned a business before the program, and an indicator that is one if an individual's score falls above the program's cut-off, and the score itself. Both in an OLS and a probit regression the indicator variable is insignificant with p-values that are larger than 0.9. Thus, there is no indication of a pre-program discontinuity in businesses owned around the cut-off.

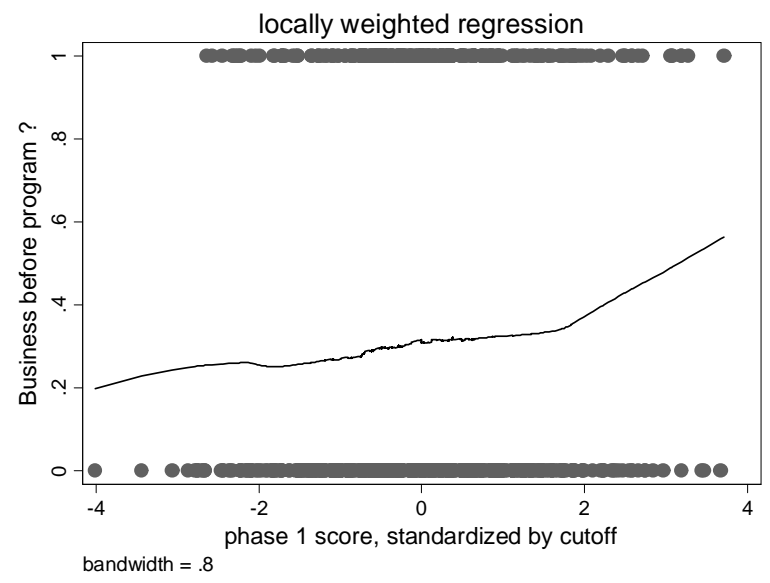

Figure 5: Is there a discontinuity in outcomes before the program? Locally weighted regression results for business owned 
Similarly, we can look at sales and employment of existing businesses of applicants in the year before the program (see figures 6 and 7). Because of the presence of some large outliers we also show results based on the logarithm of sales and employees, respectively (which drops observations with no employees and sales). The smoothed regression plots for both the levels and logs do again show no indication of a discontinuity around the cutoff. We also run regressions of log employment on the phase 1 score, separately for the applicants with scores $<0$ and those with scores $\geq 0$. Plotting the predicted regression lines on either side of the cutoff shows that the slope and the intercept of the regressions are nearly identical on both sides (figure 8). Thus, this provides further strong evidence for the absence of a discontinuity before the program starts, and thus is suggestive evidence consistent with the underlying smoothness assumption around the cutoff.
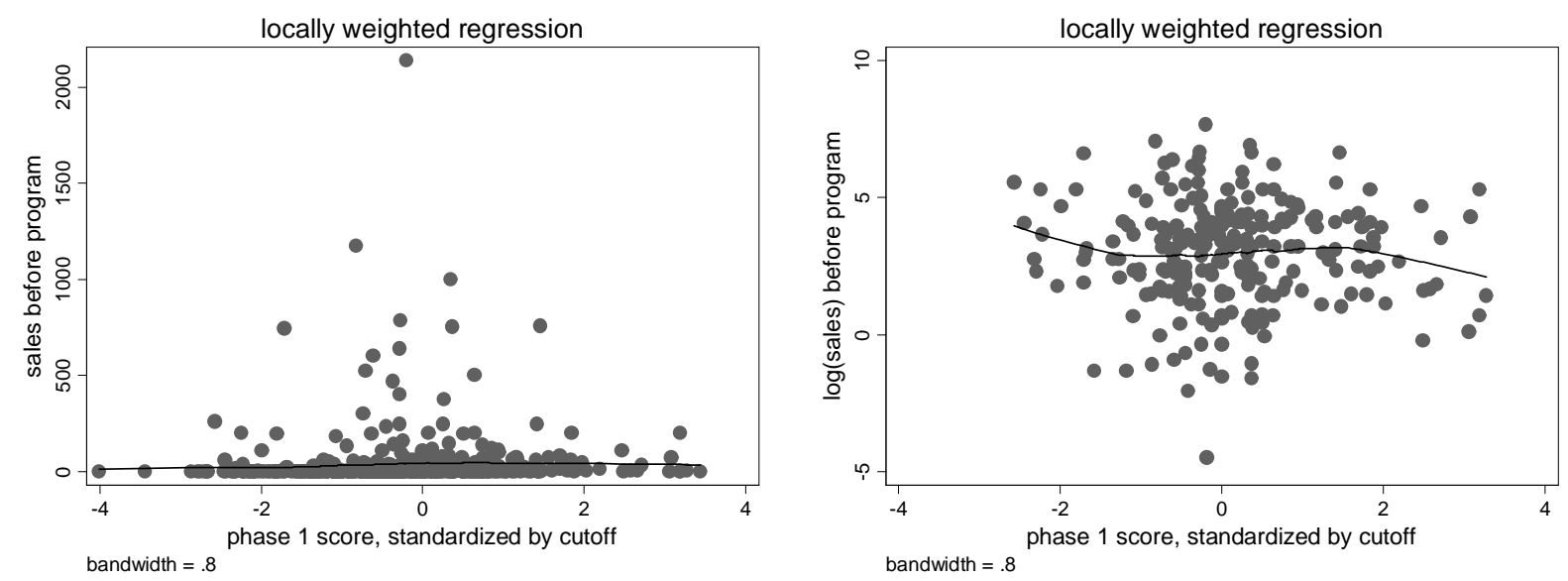

Figure 6: Is there a discontinuity in outcomes before the program? Locally weighted regression results for sales 

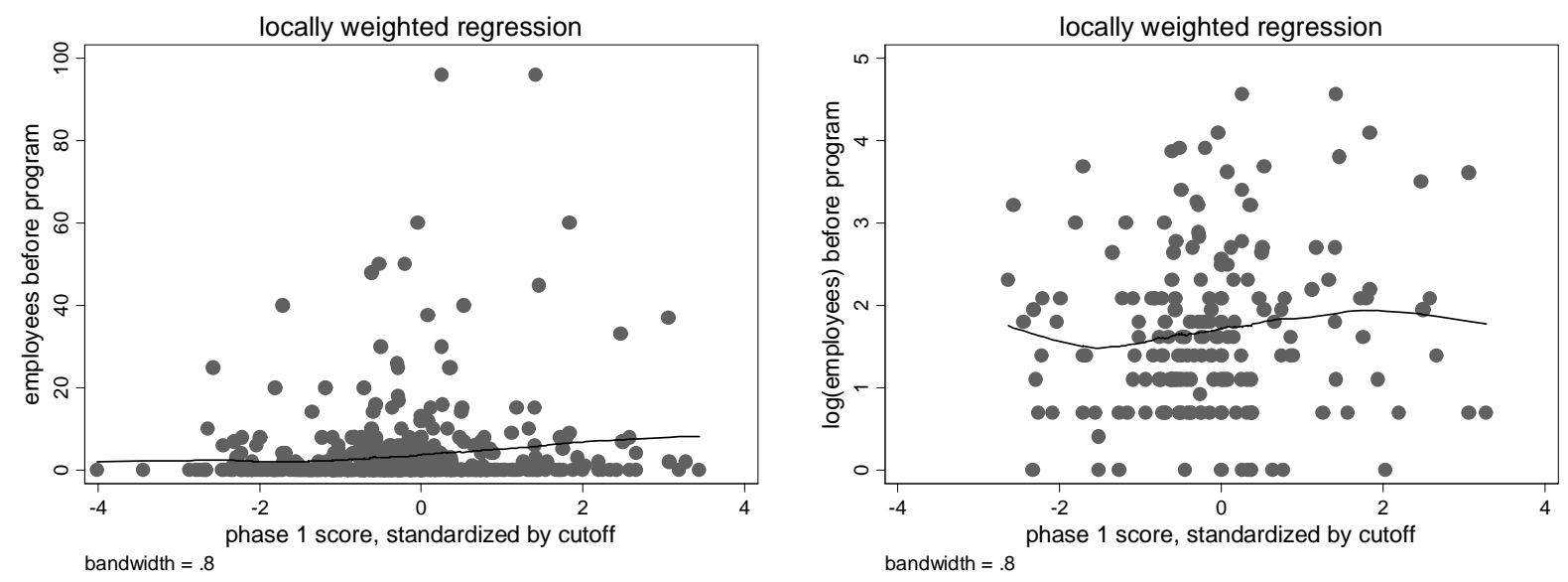

Figure 7: Is there a discontinuity in outcomes before the program? Locally weighted regression results for employees

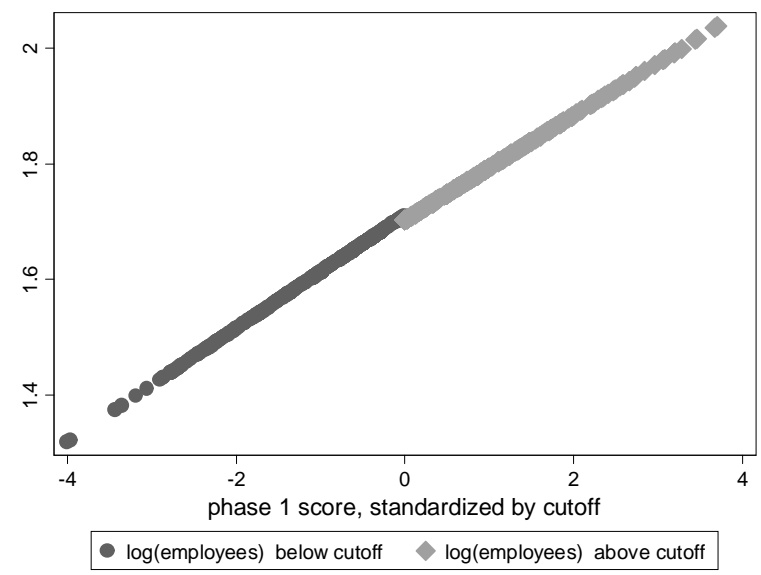

Figure 8: Is there a discontinuity in outcomes before the program? Regression results for employees 


\subsection{Discontinuities around cut-off after the program?}

In the previous section we have checked the assumption of the regression discontinuity design that there are no discontinuities at the cutoff in the absence of the intervention. The second step of this research design then looks for a break around the discontinuity after the program. Thus, as the next step of our analysis we now simply continue the previous graphical analysis, i.e. plotting outcomes against the program score, without controlling for any other variables. Specifically, we look at whether individuals started a business, or expanded a business. Considering the locally weighted regression (figure 9) we note a more pronounced change in the outcome variable around the cutoff than we observed in the same pre-program plot (figure $5) .12$

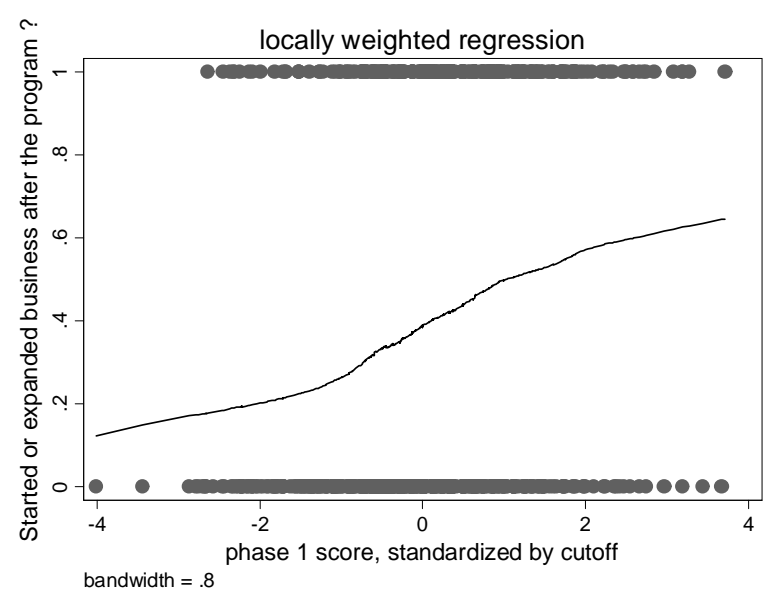

Figure 9: Is there a discontinuity after the program?

\footnotetext{
${ }^{12} \mathrm{~A}$ somewhat more formal analysis comfirms this: In a regression of an indicator variable that is equal to one if an individual owned or expanded a business after the program, and an indicator that is one if an individual's score falls above the program's cut-off, and the score itself, the indicator variable for being above the cutoff yields a highly significantly positive parameter estimate (p-value is 0.01 ). Of course, a more refined version of this kind of empirical analysis will be performed below.
} 
Before moving to a regression analysis, we start our quantitative investigation of outcome data with a look at the question whether individuals open up a business. We consider the percentage of applicants that started a business or significantly expanded a business and compare treatment and control group before and after the program. Note that we do not have a purely random assignment, and we merely report the results of the calculations of a differencein-differences analogous approach as a baseline for the regression discontinuity analysis. Table 2 shows that relative to the control group, the businesses in the training group are $22 \%$ more likely to have started or significantly expanded a business after the training. After taking into account initial differences in having a business, we find some suggestive evidence for an economically significant effect of about $25 \%$ more businesses started or expanded in the training group. Similarly, we can take a preliminary look at employment (see table 3). We have post-program data only for new businesses or those that were significantly expanded after the program, so we restrict the sample for this exercise to those businesses. We find that in new or expanding businesses the treatment group seems to have increased employment slightly faster than the control group. Again, note that this merely provides some baseline results. Because of non-random assignment this is not a difference-in-difference estimate.

\begin{tabular}{|c|c|c|c|}
\hline \multicolumn{4}{|c|}{$\begin{array}{l}\text { \% owning or expanding a business } \\
\text { (restricted to sample with pre- and post-program information) }\end{array}$} \\
\hline & intent to treat $(\mathrm{n}=444)$ & control $(\mathrm{n}=352)$ & difference \\
\hline Before & 0.34 & 0.37 & -0.03 \\
\hline After & 0.48 & 0.26 & 0.22 \\
\hline difference & 0.14 & -0.09 & 0.25 \\
\hline
\end{tabular}

Table 2: Reduced form baseline results for starting or expanding a business 


\begin{tabular}{llll}
\hline \hline \multicolumn{3}{l}{$\begin{array}{l}\text { employment for new or expanded businesses } \\
\text { (restricted to sample with pre- and post-program information) }\end{array}$} \\
& intent to treat $(\mathrm{n}=90)$ & Control $(\mathrm{n}=80)$ & difference \\
\hline Before & 7.72 & 3.86 & 3.86 \\
& & & \\
After & 11.96 & 7.71 & 4.25 \\
& & & \\
difference & 4.24 & 3.85 & 0.39 \\
\hline
\end{tabular}

Table 3: Reduced form baseline results for employment in new or expanded businesses

\section{$5 \quad$ Results}

This section presents the main results. We estimate linear probability models, and the instrumental variables regressions are two-stage least squares regressions. All regressions include country and year fixed effects. We use the following variable names: $T$ is an indicator variable that is $=1$ if an aspiring entrepreneur was trained. Similarly, $T 2$ is an indicator which is equal to 1 if the individual received the additional training in training stage 2. While $W$ is an indicator that is $=1$ if the individual is a winner of the business plan competition. These were all introduced before. "Intent to treat 1" (or short "ITT1") is equal to 1 if $S 1 \geq \overline{S 1}$; similarly, "Intent to treat 2" (short "ITT2") is equal to 1 if S2 $\geq \overline{S 2}$. No such distinction is necessary in the final cut-off stage of the competition, as in the third (winning) stage there is a sharp discontinuity, and everyone above the threshold is actually winning the prize money.

Throughout, we investigate the effect of the program on two types of outcomes related to entrepreneurial activity. We look at the start-up of new businesses and the expansion of existing businesses. To this end, we have to restrict our samples as follows: In the analysis in which start-up is the outcome of interest, we restrict the sample to individuals that did not own a business before the program. Analogously, in the analysis of expansion, we restrict the sample to entrepreneurs that already had a business before the training program. To be able to use the full sample, which increases the precision of our estimates, we also consider an outcome variable in which we pool both outcomes. This variable is equal to one if an individual with an existing business significantly expanded her business, or, for individuals without a business at the time of application for the program, launched a new business. 


\subsection{Total effect of the training program}

In this part we exploit the discontinuity that is created by the application procedure that interested applicants have to undergo. Thus, we will estimate the total effect of the training program, not just the training in the first stage, and the estimated effect will include the effect of, potentially, going on to later stages of the program. However, we are also able to get some idea about whether training is useful by itself by excluding those individuals who ended up as winners, i.e. also won some monetary prize (column 3 in table 10, and columns 3 and 7 in table 11).

Our main result is shown in table 10: Here, the dependent variable is equal to 1 if an individual with an existing business significantly expanded her business, or, for individuals without a business at the time of application for the program, launched a new business. In all four specifications of column 1-4 we find strong effects of the business plan competition program on entrepreneurial activity, i.e. business start-up/launch or expansion of existing businesses. Column 3 shows that these results are robust to excluding the eventual winners of the business plan competition (who receive some prize money). This suggests that the total training effect is not simply due to the financial aspects of the training. The results are also robust to allowing the treatment to vary with the phase 1 score (column 4).

Looking at launch and expansion separately (table 11), we find strong effects on business expansion, while we do not find a significant effect of the program on launching of businesses, though the point estimates for intent to treat effect (ITT1) and training (T) are positive.

The parameter estimates imply a 9 to 11 percentage points higher probability of opening a business (for individuals without a business before the start of the program) in the treatment group and a 23 to 26 percentage points higher probability of expanding a business (for individuals with an existing business before the program) in the treatment group.

Regarding other variables of interest, we note that there is no difference between male and female applicants in the baseline probability that a business is launched or expanded. ${ }^{13}$ On the other hand, we find strong age effects for launching a business: older individuals are much more likely to launch a business than younger individuals.

\footnotetext{
${ }^{13}$ We will further investigate the differences in the training effect between male and female individuals in a section below.
} 


\begin{tabular}{|c|c|c|c|c|}
\hline \multicolumn{5}{|c|}{ Dependent variable $=1$ if new business launched or existing business expanded } \\
\hline & $\begin{array}{l}\text { baseline with intent to } \\
\text { treat } \\
\text { (1) }\end{array}$ & $\begin{array}{l}\text { using the training } \\
\text { indicator variable, IV } \\
\text { (2) }\end{array}$ & $\begin{array}{l}\text { exclude winner, IV } \\
\text { (3) }\end{array}$ & $\begin{array}{l}\text { treatment varies with } \\
\text { score, IV } \\
(4)\end{array}$ \\
\hline Intent to treat 1 & $\begin{array}{l}0.171 \\
(0.058) * * *\end{array}$ & & & \\
\hline received training $(\mathrm{T})$ & & $\begin{array}{l}0.197 \\
(0.066) * * *\end{array}$ & $\begin{array}{l}0.172 \\
(0.067)^{* *}\end{array}$ & $\begin{array}{l}0.203 \\
(0.067)^{* * * *}\end{array}$ \\
\hline $\mathrm{T} * \mathrm{~S} 1$ & & & & $\begin{array}{l}0.133 \\
(0.147)\end{array}$ \\
\hline S1 (phase 1 score) & $\begin{array}{l}0.039 \\
(0.025)\end{array}$ & $\begin{array}{l}0.036 \\
(0.026)\end{array}$ & $\begin{array}{l}0.031 \\
(0.026)\end{array}$ & $\begin{array}{l}-0.034 \\
(0.083)\end{array}$ \\
\hline S1 squared & $\begin{array}{l}0.004 \\
(0.009)\end{array}$ & $\begin{array}{l}0.005 \\
(0.009)\end{array}$ & $\begin{array}{l}0.004 \\
(0.009)\end{array}$ & $\begin{array}{l}-0.016 \\
(0.025)\end{array}$ \\
\hline male & $\begin{array}{l}-0.001 \\
(0.043)\end{array}$ & $\begin{array}{l}-0.006 \\
(0.043)\end{array}$ & $\begin{array}{l}-0.007 \\
(0.043)\end{array}$ & $\begin{array}{l}-0.005 \\
(0.043)\end{array}$ \\
\hline age & $\begin{array}{l}0.032 \\
(0.010)^{* * *}\end{array}$ & $\begin{array}{l}0.032 \\
(0.010) * * *\end{array}$ & $\begin{array}{l}0.030 \\
(0.010)^{* * *}\end{array}$ & $\begin{array}{l}0.033 \\
(0.010)^{* * *}\end{array}$ \\
\hline age squared & $\begin{array}{l}-0.000 \\
(0.000)^{* * *}\end{array}$ & $\begin{array}{l}-0.000 \\
(0.000)^{* * *}\end{array}$ & $\begin{array}{l}-0.000 \\
(0.000)^{* * *}\end{array}$ & $\begin{array}{l}-0.000 \\
(0.000) * * *\end{array}$ \\
\hline Nicaragua & $\begin{array}{l}-0.015 \\
(0.061)\end{array}$ & $\begin{array}{l}-0.021 \\
(0.061)\end{array}$ & $\begin{array}{l}-0.038 \\
(0.063)\end{array}$ & $\begin{array}{l}-0.007 \\
(0.063)\end{array}$ \\
\hline El Salvador & $\begin{array}{l}0.089 \\
(0.077)\end{array}$ & $\begin{array}{l}0.070 \\
(0.077)\end{array}$ & $\begin{array}{l}0.069 \\
(0.079)\end{array}$ & $\begin{array}{l}0.091 \\
(0.080)\end{array}$ \\
\hline year $=2003$ & $\begin{array}{l}0.034 \\
(0.072)\end{array}$ & $\begin{array}{l}0.039 \\
(0.071)\end{array}$ & $\begin{array}{l}0.038 \\
(0.073)\end{array}$ & $\begin{array}{l}0.043 \\
(0.071)\end{array}$ \\
\hline year $=2004$ & $\begin{array}{l}0.144 \\
(0.119)\end{array}$ & $\begin{array}{l}0.144 \\
(0.118)\end{array}$ & $\begin{array}{l}0.119 \\
(0.123)\end{array}$ & $\begin{array}{l}0.153 \\
(0.118)\end{array}$ \\
\hline year $=2005$ & $\begin{array}{l}-0.055 \\
(0.093)\end{array}$ & $\begin{array}{l}-0.052 \\
(0.092)\end{array}$ & $\begin{array}{l}-0.068 \\
(0.095)\end{array}$ & $\begin{array}{l}-0.037 \\
(0.094)\end{array}$ \\
\hline Constant & $\begin{array}{l}-0.362 \\
(0.223)\end{array}$ & $\begin{array}{l}-0.362 \\
(0.221)\end{array}$ & $\begin{array}{l}-0.324 \\
(0.226)\end{array}$ & $\begin{array}{l}-0.429 \\
(0.234)^{*}\end{array}$ \\
\hline Observations & 655 & 655 & 619 & 655 \\
\hline R-squared & 0.14 & 0.16 & 0.14 & 0.16 \\
\hline
\end{tabular}

Figure 10: The effect of training on business launch or expansion 


\begin{tabular}{|c|c|c|c|c|c|c|c|c|}
\hline \multirow[t]{2}{*}{ Dependent variable } & \multicolumn{4}{|c|}{$=1$ if new business launched } & \multicolumn{4}{|c|}{$=1$ if existing business expanded } \\
\hline & $(1)$ & (2) & $\begin{array}{l}\text { exclude } \\
\text { winner, IV } \\
(3) \\
\end{array}$ & $\begin{array}{l}\text { treatment } \\
\text { varies with } \\
\text { score, IV } \\
(4) \\
\end{array}$ & $(5)$ & $(6)$ & $\begin{array}{l}\text { exclude } \\
\text { winner, IV } \\
(7)\end{array}$ & $\begin{array}{l}\text { treatment } \\
\text { varies with } \\
\text { score, IV } \\
(8) \\
\end{array}$ \\
\hline Intent to treat 1 & $\begin{array}{l}0.087 \\
(0.068)\end{array}$ & & & & $\begin{array}{l}0.227 \\
(0.082) * * *\end{array}$ & & & \\
\hline received training $(\mathrm{T})$ & & $\begin{array}{l}0.094 \\
(0.073)\end{array}$ & $\begin{array}{l}0.059 \\
(0.073)\end{array}$ & $\begin{array}{l}0.113 \\
(0.076)\end{array}$ & & $\begin{array}{l}0.260 \\
(0.093) * * *\end{array}$ & $\begin{array}{l}0.234 \\
(0.096)^{* *}\end{array}$ & $\begin{array}{l}0.263 \\
(0.094) * * *\end{array}$ \\
\hline $\mathrm{T} * \mathrm{~S} 1$ & & & & $\begin{array}{l}0.199 \\
(0.171)\end{array}$ & & & & $\begin{array}{l}0.145 \\
(0.201)\end{array}$ \\
\hline S1 (phase 1 score) & $\begin{array}{l}0.035 \\
(0.029)\end{array}$ & $\begin{array}{l}0.035 \\
(0.030)\end{array}$ & $\begin{array}{l}0.027 \\
(0.030)\end{array}$ & $\begin{array}{l}-0.072 \\
(0.097)\end{array}$ & $\begin{array}{l}0.012 \\
(0.038)\end{array}$ & $\begin{array}{l}0.011 \\
(0.037)\end{array}$ & $\begin{array}{l}0.012 \\
(0.039)\end{array}$ & $\begin{array}{l}-0.067 \\
(0.115)\end{array}$ \\
\hline S1 squared & $\begin{array}{l}-0.001 \\
(0.010)\end{array}$ & $\begin{array}{l}-0.001 \\
(0.010)\end{array}$ & $\begin{array}{l}-0.004 \\
(0.010)\end{array}$ & $\begin{array}{l}-0.034 \\
(0.030)\end{array}$ & $\begin{array}{l}0.007 \\
(0.013)\end{array}$ & $\begin{array}{l}0.007 \\
(0.013)\end{array}$ & $\begin{array}{l}0.008 \\
(0.014)\end{array}$ & $\begin{array}{l}-0.016 \\
(0.034)\end{array}$ \\
\hline male & $\begin{array}{l}0.011 \\
(0.049)\end{array}$ & $\begin{array}{l}0.011 \\
(0.048)\end{array}$ & $\begin{array}{l}-0.002 \\
(0.048)\end{array}$ & $\begin{array}{l}0.009 \\
(0.049)\end{array}$ & $\begin{array}{l}-0.036 \\
(0.064)\end{array}$ & $\begin{array}{l}-0.044 \\
(0.064)\end{array}$ & $\begin{array}{l}-0.042 \\
(0.067)\end{array}$ & $\begin{array}{l}-0.043 \\
(0.064)\end{array}$ \\
\hline age & $\begin{array}{l}0.024 \\
(0.011)^{* *}\end{array}$ & $\begin{array}{l}0.024 \\
(0.011) * *\end{array}$ & $\begin{array}{l}0.023 \\
(0.011)^{* *}\end{array}$ & $\begin{array}{l}0.025 \\
(0.011)^{* *}\end{array}$ & $\begin{array}{l}-0.005 \\
(0.016)\end{array}$ & $\begin{array}{l}-0.006 \\
(0.016)\end{array}$ & $\begin{array}{l}-0.008 \\
(0.016)\end{array}$ & $\begin{array}{l}-0.005 \\
(0.016)\end{array}$ \\
\hline age squared & $\begin{array}{l}-0.000 \\
(0.000)^{* *}\end{array}$ & $\begin{array}{l}-0.000 \\
(0.000)^{* *}\end{array}$ & $\begin{array}{l}-0.000 \\
(0.000)^{* *}\end{array}$ & $\begin{array}{l}-0.000 \\
(0.000)^{* *}\end{array}$ & $\begin{array}{l}0.000 \\
(0.000)\end{array}$ & $\begin{array}{l}0.000 \\
(0.000)\end{array}$ & $\begin{array}{l}0.000 \\
(0.000)\end{array}$ & $\begin{array}{l}0.000 \\
(0.000)\end{array}$ \\
\hline Nicaragua & $\begin{array}{l}-0.030 \\
(0.072)\end{array}$ & $\begin{array}{l}-0.032 \\
(0.071)\end{array}$ & $\begin{array}{l}-0.037 \\
(0.071)\end{array}$ & $\begin{array}{l}-0.011 \\
(0.074)\end{array}$ & $\begin{array}{l}-0.025 \\
(0.085)\end{array}$ & $\begin{array}{l}-0.039 \\
(0.085)\end{array}$ & $\begin{array}{l}-0.057 \\
(0.090)\end{array}$ & $\begin{array}{l}-0.023 \\
(0.088)\end{array}$ \\
\hline El Salvador & $\begin{array}{l}-0.112 \\
(0.106)\end{array}$ & $\begin{array}{l}-0.101 \\
(0.106)\end{array}$ & $\begin{array}{l}-0.096 \\
(0.103)\end{array}$ & $\begin{array}{l}-0.069 \\
(0.109)\end{array}$ & $\begin{array}{l}-0.523 \\
(0.118) * * *\end{array}$ & $\begin{array}{l}-0.542 \\
(0.118) * * *\end{array}$ & $\begin{array}{l}-0.511 \\
(0.124) * * *\end{array}$ & $\begin{array}{l}-0.520 \\
(0.122)^{* * * *}\end{array}$ \\
\hline year $=2003$ & $\begin{array}{l}-0.118 \\
(0.076)\end{array}$ & $\begin{array}{l}-0.112 \\
(0.076)\end{array}$ & $\begin{array}{l}-0.125 \\
(0.076)\end{array}$ & $\begin{array}{l}-0.104 \\
(0.076)\end{array}$ & $\begin{array}{l}-0.041 \\
(0.127)\end{array}$ & $\begin{array}{l}-0.055 \\
(0.125)\end{array}$ & $\begin{array}{l}-0.060 \\
(0.128)\end{array}$ & $\begin{array}{l}-0.058 \\
(0.126)\end{array}$ \\
\hline year $=2004$ & $\begin{array}{l}-0.205 \\
(0.149)\end{array}$ & $\begin{array}{l}-0.186 \\
(0.149)\end{array}$ & $\begin{array}{l}-0.208 \\
(0.148)\end{array}$ & $\begin{array}{l}-0.169 \\
(0.150)\end{array}$ & $\begin{array}{l}-0.497 \\
(0.185)^{* * *}\end{array}$ & $\begin{array}{l}-0.498 \\
(0.183) * * *\end{array}$ & $\begin{array}{l}-0.444 \\
(0.195)^{* *}\end{array}$ & $\begin{array}{l}-0.498 \\
(0.184) * * *\end{array}$ \\
\hline year $=2005$ & $\begin{array}{l}-0.337 \\
(0.121)^{* * *}\end{array}$ & $\begin{array}{l}-0.317 \\
(0.123)^{* *}\end{array}$ & $\begin{array}{l}-0.329 \\
(0.121)^{* * *}\end{array}$ & $\begin{array}{l}-0.286 \\
(0.126)^{* *}\end{array}$ & $\begin{array}{l}-0.843 \\
(0.157) * * *\end{array}$ & $\begin{array}{l}-0.841 \\
(0.155) * * *\end{array}$ & $\begin{array}{l}-0.834 \\
(0.160) * * *\end{array}$ & $\begin{array}{l}-0.837 \\
(0.156) * * *\end{array}$ \\
\hline Constant & $\begin{array}{l}0.020 \\
(0.246)\end{array}$ & $\begin{array}{l}-0.003 \\
(0.249)\end{array}$ & $\begin{array}{l}0.053 \\
(0.246)\end{array}$ & $\begin{array}{l}-0.104 \\
(0.265)\end{array}$ & $\begin{array}{l}1.410 \\
(0.378) * * *\end{array}$ & $\begin{array}{l}1.418 \\
(0.374) * * *\end{array}$ & $\begin{array}{l}1.459 \\
(0.387) * * *\end{array}$ & $\begin{array}{l}1.356 \\
(0.386) * * *\end{array}$ \\
\hline Observations & 392 & 392 & 374 & 392 & 249 & 249 & 232 & 249 \\
\hline R-squared & 0.12 & 0.13 & 0.11 & 0.13 & 0.34 & 0.35 & 0.34 & 0.35 \\
\hline
\end{tabular}

Notes: Standard errors in parentheses; * significant at 10\%; ** significant at 5\%; *** significant at 1\%; omitted country is Guatemala, omitted year is 2002; instruments are intent to treat indicator (in columns 2, 3, 6 and 7) and intent to treat indicator interacted with score 1 (columns 4 and 8); for further explanation see the methodology section.

Figure 11: The effect of training on business launch or expansion, separate regressions 


\subsection{Effect of second stage training, conditional on first stage train- ing}

Next, we study the effect of entering the second stage training on business outcomes, conditional on the first training stage. Note again that the estimated effect includes the option of winning a monetary prize at the end of the competition. Again, we first look at the pooled outcome variable, which is equal to 1 if either an existing business was expanded or a new business was launched. Table 12 shows the results. Overall, we find a strong effect of the second stage training on this combined outcome variable. Looking at launch and expansion separately (table 13), we see that the significant combined effect is mainly due to a significant effect of this part of the training program on launching a new business. Again, the point estimate for intent to treat and training variables (ITT2 and T2) in columns 5-8 are positive in 3 of the 4 specifications, but not significant. 


\begin{tabular}{|c|c|c|c|c|}
\hline \multicolumn{5}{|c|}{ "Dependent variable $=1$ if new business launched or existing business expanded } \\
\hline & $\begin{array}{l}\text { baseline with intent to } \\
\text { treat } \\
\text { (1) }\end{array}$ & $\begin{array}{l}\text { using the training } \\
\text { indicator variable, IV } \\
\text { (2) }\end{array}$ & $\begin{array}{l}\text { exclude winner, IV } \\
\text { (3) }\end{array}$ & $\begin{array}{l}\text { treatment varies with } \\
\text { score, IV } \\
\text { (4) }\end{array}$ \\
\hline Intent to treat 2 & $\begin{array}{l}0.172 \\
(0.092)^{*}\end{array}$ & & & \\
\hline $\begin{array}{l}\text { received second stage } \\
\text { training }(\mathrm{T} 2)\end{array}$ & & $\begin{array}{l}0.183 \\
(0.098)^{*}\end{array}$ & $\begin{array}{l}0.111 \\
(0.112)\end{array}$ & $\begin{array}{l}0.195 \\
(0.099) *\end{array}$ \\
\hline $\mathrm{T} 2 * \mathrm{~S} 1$ & & & & $\begin{array}{l}0.228 \\
(0.197)\end{array}$ \\
\hline S2 (phase 1 score) & $\begin{array}{l}0.014 \\
(0.040)\end{array}$ & $\begin{array}{l}0.011 \\
(0.041)\end{array}$ & $\begin{array}{l}-0.004 \\
(0.047)\end{array}$ & $\begin{array}{l}-0.105 \\
(0.109)\end{array}$ \\
\hline S2 squared & $\begin{array}{l}-0.014 \\
(0.014)\end{array}$ & $\begin{array}{l}-0.012 \\
(0.014)\end{array}$ & $\begin{array}{l}-0.018 \\
(0.015)\end{array}$ & $\begin{array}{l}-0.048 \\
(0.034)\end{array}$ \\
\hline male & $\begin{array}{l}0.011 \\
(0.065)\end{array}$ & $\begin{array}{l}0.012 \\
(0.065)\end{array}$ & $\begin{array}{l}0.013 \\
(0.070)\end{array}$ & $\begin{array}{l}0.014 \\
(0.065)\end{array}$ \\
\hline age & $\begin{array}{l}0.059 \\
(0.015)^{* * *}\end{array}$ & $\begin{array}{l}0.058 \\
(0.015)^{* * *}\end{array}$ & $\begin{array}{l}0.062 \\
(0.016)^{* * *}\end{array}$ & $\begin{array}{l}0.059 \\
(0.015)^{* * *}\end{array}$ \\
\hline age squared & $\begin{array}{l}-0.001 \\
(0.000)^{* * *}\end{array}$ & $\begin{array}{l}-0.001 \\
(0.000)^{* * *}\end{array}$ & $\begin{array}{l}-0.001 \\
(0.000)^{* * *}\end{array}$ & $\begin{array}{l}-0.001 \\
(0.000) * * *\end{array}$ \\
\hline Nicaragua & $\begin{array}{l}0.037 \\
(0.098)\end{array}$ & $\begin{array}{l}0.038 \\
(0.098)\end{array}$ & $\begin{array}{l}0.006 \\
(0.111)\end{array}$ & $\begin{array}{l}0.044 \\
(0.098)\end{array}$ \\
\hline El Salvador & $\begin{array}{l}0.380 \\
(0.108) * * *\end{array}$ & $\begin{array}{l}0.381 \\
(0.108) * * *\end{array}$ & $\begin{array}{l}0.401 \\
(0.116)^{* * *}\end{array}$ & $\begin{array}{l}0.381 \\
(0.108) * * *\end{array}$ \\
\hline year $=2003$ & $\begin{array}{l}0.052 \\
(0.091)\end{array}$ & $\begin{array}{l}0.038 \\
(0.091)\end{array}$ & $\begin{array}{l}0.055 \\
(0.096)\end{array}$ & $\begin{array}{l}0.053 \\
(0.092)\end{array}$ \\
\hline year $=2004$ & $\begin{array}{l}0.353 \\
(0.154) * *\end{array}$ & $\begin{array}{l}0.354 \\
(0.154)^{* *}\end{array}$ & $\begin{array}{l}0.375 \\
(0.170)^{* *}\end{array}$ & $\begin{array}{l}0.362 \\
(0.154) * *\end{array}$ \\
\hline year $=2005$ & $\begin{array}{l}0.060 \\
(0.112)\end{array}$ & $\begin{array}{l}0.061 \\
(0.113)\end{array}$ & $\begin{array}{l}0.063 \\
(0.119)\end{array}$ & $\begin{array}{l}0.064 \\
(0.113)\end{array}$ \\
\hline Constant & $\begin{array}{l}-0.947 \\
(0.336) * * *\end{array}$ & $\begin{array}{l}-0.946 \\
(0.336) * * *\end{array}$ & $\begin{array}{l}-1.053 \\
(0.362)^{* * *}\end{array}$ & $\begin{array}{l}-1.034 \\
(0.346) * * *\end{array}$ \\
\hline Observations & 272 & 272 & 236 & 272 \\
\hline R-squared & 0.19 & 0.18 & 0.18 & 0.19 \\
\hline
\end{tabular}

Figure 12: The effect of the second stage of training on business launch or expansion 


\begin{tabular}{|c|c|c|c|c|c|c|c|c|}
\hline \multirow[t]{2}{*}{ Dependent variable } & \multicolumn{4}{|c|}{$=1$ if new business launched } & \multicolumn{4}{|c|}{$=1$ if existing business expanded } \\
\hline & $(1)$ & (2) & $\begin{array}{l}\text { exclude } \\
\text { winner, IV } \\
\text { (3) }\end{array}$ & $\begin{array}{l}\text { treatment } \\
\text { varies with } \\
\text { score, IV } \\
(4)\end{array}$ & $(5)$ & IV & $\begin{array}{l}\text { exclude } \\
\text { winner, IV } \\
(7)\end{array}$ & $\begin{array}{l}\text { treatment } \\
\text { varies with } \\
\text { score, IV } \\
(8)\end{array}$ \\
\hline Intent to treat 2 & $\begin{array}{l}0.420 \\
(0.129) * * *\end{array}$ & & & & $\begin{array}{l}0.065 \\
(0.116)\end{array}$ & & & \\
\hline $\begin{array}{l}\text { received second stage } \\
\text { training }(\mathrm{T} 2)\end{array}$ & & $\begin{array}{l}0.472 \\
(0.146)^{* * *}\end{array}$ & $\begin{array}{l}0.458 \\
(0.167) * * *\end{array}$ & $\begin{array}{l}0.490 \\
(0.147)^{* * *}\end{array}$ & & $\begin{array}{l}0.067 \\
(0.121)\end{array}$ & $\begin{array}{l}-0.008 \\
(0.140)\end{array}$ & $\begin{array}{l}0.064 \\
(0.123)\end{array}$ \\
\hline $\mathrm{T} 2 * \mathrm{~S} 1$ & & & & $\begin{array}{l}0.399 \\
(0.286)\end{array}$ & & & & $\begin{array}{l}-0.046 \\
(0.224)\end{array}$ \\
\hline S2 (phase 1 score) & $\begin{array}{l}-0.027 \\
(0.063)\end{array}$ & $\begin{array}{l}-0.040 \\
(0.066)\end{array}$ & $\begin{array}{l}-0.106 \\
(0.082)\end{array}$ & $\begin{array}{l}-0.249 \\
(0.168)\end{array}$ & $\begin{array}{l}-0.020 \\
(0.046)\end{array}$ & $\begin{array}{l}-0.021 \\
(0.047)\end{array}$ & $\begin{array}{l}-0.016 \\
(0.051)\end{array}$ & $\begin{array}{l}0.002 \\
(0.122)\end{array}$ \\
\hline $\mathrm{S} 2$ squared & $\begin{array}{l}-0.024 \\
(0.022)\end{array}$ & $\begin{array}{l}-0.019 \\
(0.022)\end{array}$ & $\begin{array}{l}-0.041 \\
(0.026)\end{array}$ & $\begin{array}{l}-0.088 \\
(0.055)\end{array}$ & $\begin{array}{l}0.005 \\
(0.015)\end{array}$ & $\begin{array}{l}0.005 \\
(0.015)\end{array}$ & $\begin{array}{l}0.005 \\
(0.016)\end{array}$ & $\begin{array}{l}0.012 \\
(0.036)\end{array}$ \\
\hline male & $\begin{array}{l}0.046 \\
(0.084)\end{array}$ & $\begin{array}{l}0.046 \\
(0.084)\end{array}$ & $\begin{array}{l}0.006 \\
(0.089)\end{array}$ & $\begin{array}{l}0.058 \\
(0.085)\end{array}$ & $\begin{array}{l}0.024 \\
(0.085)\end{array}$ & $\begin{array}{l}0.027 \\
(0.084)\end{array}$ & $\begin{array}{l}0.054 \\
(0.094)\end{array}$ & $\begin{array}{l}0.030 \\
(0.086)\end{array}$ \\
\hline age & $\begin{array}{l}0.033 \\
(0.019)^{*}\end{array}$ & $\begin{array}{l}0.029 \\
(0.019)\end{array}$ & $\begin{array}{l}0.031 \\
(0.020)\end{array}$ & $\begin{array}{l}0.033 \\
(0.019)^{*}\end{array}$ & $\begin{array}{l}0.019 \\
(0.021)\end{array}$ & $\begin{array}{l}0.019 \\
(0.021)\end{array}$ & $\begin{array}{l}0.016 \\
(0.023)\end{array}$ & $\begin{array}{l}0.019 \\
(0.021)\end{array}$ \\
\hline age squared & $\begin{array}{l}-0.000 \\
(0.000)^{*}\end{array}$ & $\begin{array}{l}-0.000 \\
(0.000)^{*}\end{array}$ & $\begin{array}{l}-0.000 \\
(0.000)\end{array}$ & $\begin{array}{l}-0.000 \\
(0.000)^{*}\end{array}$ & $\begin{array}{l}-0.000 \\
(0.000)\end{array}$ & $\begin{array}{l}-0.000 \\
(0.000)\end{array}$ & $\begin{array}{l}-0.000 \\
(0.000)\end{array}$ & $\begin{array}{l}-0.000 \\
(0.000)\end{array}$ \\
\hline Nicaragua & $\begin{array}{l}-0.016 \\
(0.131)\end{array}$ & $\begin{array}{l}-0.015 \\
(0.132)\end{array}$ & $\begin{array}{l}-0.065 \\
(0.141)\end{array}$ & $\begin{array}{l}-0.004 \\
(0.132)\end{array}$ & $\begin{array}{l}-0.003 \\
(0.113)\end{array}$ & $\begin{array}{l}-0.002 \\
(0.113)\end{array}$ & $\begin{array}{l}-0.002 \\
(0.135)\end{array}$ & $\begin{array}{l}-0.003 \\
(0.114)\end{array}$ \\
\hline El Salvador & $\begin{array}{l}0.173 \\
(0.242)\end{array}$ & $\begin{array}{l}0.184 \\
(0.243)\end{array}$ & $\begin{array}{l}0.134 \\
(0.246)\end{array}$ & $\begin{array}{l}0.164 \\
(0.244)\end{array}$ & $\begin{array}{l}-0.466 \\
(0.132) * * *\end{array}$ & $\begin{array}{l}-0.464 \\
(0.132) * * *\end{array}$ & $\begin{array}{l}-0.390 \\
(0.145)^{* * *}\end{array}$ & $\begin{array}{l}-0.461 \\
(0.134)^{* * *}\end{array}$ \\
\hline year $=2003$ & $\begin{array}{l}-0.139 \\
(0.105)\end{array}$ & $\begin{array}{l}-0.195 \\
(0.107)^{*}\end{array}$ & $\begin{array}{l}-0.199 \\
(0.113)^{*}\end{array}$ & $\begin{array}{l}-0.162 \\
(0.109)\end{array}$ & $\begin{array}{l}0.015 \\
(0.145)\end{array}$ & $\begin{array}{l}0.014 \\
(0.145)\end{array}$ & $\begin{array}{l}0.004 \\
(0.149)\end{array}$ & $\begin{array}{l}0.012 \\
(0.146)\end{array}$ \\
\hline year $=2004$ & $\begin{array}{l}0.065 \\
(0.279)\end{array}$ & $\begin{array}{l}0.076 \\
(0.280)\end{array}$ & $\begin{array}{l}0.065 \\
(0.288)\end{array}$ & $\begin{array}{l}0.063 \\
(0.280)\end{array}$ & $\begin{array}{l}-0.448 \\
(0.206)^{* *}\end{array}$ & $\begin{array}{l}-0.445 \\
(0.207)^{* *}\end{array}$ & $\begin{array}{l}-0.380 \\
(0.234)\end{array}$ & $\begin{array}{l}-0.444 \\
(0.208)^{* *}\end{array}$ \\
\hline year $=2005$ & $\begin{array}{l}-0.218 \\
(0.241)\end{array}$ & $\begin{array}{l}-0.205 \\
(0.242)\end{array}$ & $\begin{array}{l}-0.251 \\
(0.245)\end{array}$ & $\begin{array}{l}-0.216 \\
(0.243)\end{array}$ & $\begin{array}{l}-0.810 \\
(0.170)^{* * *}\end{array}$ & $\begin{array}{l}-0.808 \\
(0.171)^{* * * *}\end{array}$ & $\begin{array}{l}-0.807 \\
(0.178)^{* * *}\end{array}$ & $\begin{array}{l}-0.804 \\
(0.172)^{* * *}\end{array}$ \\
\hline Constant & $\begin{array}{l}-0.303 \\
(0.453)\end{array}$ & $\begin{array}{l}-0.257 \\
(0.454)\end{array}$ & $\begin{array}{l}-0.242 \\
(0.476)\end{array}$ & $\begin{array}{l}-0.437 \\
(0.473)\end{array}$ & $\begin{array}{l}1.030 \\
(0.488)^{* *}\end{array}$ & $\begin{array}{l}1.019 \\
(0.493)^{* *}\end{array}$ & $\begin{array}{l}1.013 \\
(0.532)^{*}\end{array}$ & $\begin{array}{l}1.025 \\
(0.497)^{* *}\end{array}$ \\
\hline Observations & 150 & 150 & 132 & 150 & 108 & 108 & 91 & 108 \\
\hline R-squared & 0.27 & 0.26 & 0.22 & 0.27 & 0.46 & 0.46 & 0.49 & 0.46 \\
\hline
\end{tabular}

Notes: Standard errors in parentheses; * significant at 10\%; ** significant at 5\%; *** significant at 1\%; omitted country is Guatemala, omitted year is 2002; instruments are intent to treat 2 indicator (in columns 2, 3, 6 and 7) and intent to treat 2 indicator interacted with score 2 (columns 4 and 8); for further explanation see the methodology section.

Figure 13: The effect of the second stage of training on business launch or expansion, separate regressions 


\subsection{Effect of winning, conditional on second stage training}

The final winning-stage is different for two reasons. First, as we have seen above, the discontinuity at this stage is sharp, therefore we do not have to instrument the indicator variable of interest ( $W$, which is 1 if the individual won the competition). Second, we also argue that at the last stage individuals are fairly similar to each other in terms of their unobservables, because there are only a few of them, which all have gone through two rounds of selections already, and that consequently they are all "close" to the cutoff, which would allow us to exclude $f^{\prime \prime}\left(S 3_{i}\right)$. This matters in practical terms, because at this last stage we have relatively few observations, so increasing the degrees of freedom matters for our econometric analysis. Thus, our preferred specification does not condition on phase 3 score (Greenstone and Moretti, 2004, use a similar approach in the context of location decisions of industrial plants). However, we also show specifications that include the score. In addition, unlike before, in this stage it is also easier to name the treatment more specifically. In the earlier training stages the training is composed of several parts and it is not possible to identify separately which training component or which group of components is responsible for results. Here, however, the most significant part of the additional treatment is the prize money.

We find economically significant changes in the probability of starting or expanding a business due to winning the competition, and the coefficient on the winner variable is statistically significant in the specifications that do not include the score (S3). ${ }^{14}$ Looking at the launch and expansion of businesses separately, we find that the effect is stronger for launching a business (table 15). However, this particular finding is statistically significant only in one specification, and for the creation of businesses. This may well be explained by the relatively small number of observations in this last stage of the program.

\footnotetext{
${ }^{14}$ In the specification that includes the score (column 2), the p-value for the estimate on winner is 0.170.
} 


\begin{tabular}{|c|c|c|c|c|c|}
\hline \multicolumn{6}{|c|}{ Dependent variable $=1$ if new business launched or existing business expanded } \\
\hline & baseline & include scores & $\begin{array}{l}\text { treatment varies } \\
\text { with score } \\
\text { (3) }\end{array}$ & $\begin{array}{l}\text { treatment varies } \\
\text { with score, include } \\
\log \text { (prizemoney) } \\
\text { (4) }\end{array}$ & $\begin{array}{l}\text { treatment varies } \\
\text { with score, } \\
\text { include } \\
\text { prizemoney } \\
\text { (5) }\end{array}$ \\
\hline winner $(\mathrm{W})$ & $\begin{array}{l}0.323 \\
(0.087) * * *\end{array}$ & $\begin{array}{l}0.195 \\
(0.141)\end{array}$ & $\begin{array}{l}0.173 \\
(0.154)\end{array}$ & & \\
\hline S3 & & $\begin{array}{l}0.093 \\
(0.091)\end{array}$ & $\begin{array}{l}0.142 \\
(0.164)\end{array}$ & $\begin{array}{l}0.070 \\
(0.112)\end{array}$ & $\begin{array}{l}0.233 \\
(0.151)\end{array}$ \\
\hline S3 squared & & $\begin{array}{l}0.013 \\
(0.028)\end{array}$ & $\begin{array}{l}0.026 \\
(0.047)\end{array}$ & $\begin{array}{l}0.029 \\
(0.047)\end{array}$ & $\begin{array}{l}0.048 \\
(0.045)\end{array}$ \\
\hline $\mathrm{W} * \mathrm{~S} 3$ & & & $\begin{array}{l}-0.097 \\
(0.268)\end{array}$ & & \\
\hline $\log ($ prizemoney+0.001) & & & & $\begin{array}{l}0.017 \\
(0.017)\end{array}$ & \\
\hline $\log ($ prizemoney +0.001$) * S 3$ & & & & $\begin{array}{l}-0.012 \\
(0.029)\end{array}$ & \\
\hline prizemoney/1000 & & & & & $\begin{array}{l}0.007 \\
(0.013)\end{array}$ \\
\hline prizemoney*S3 & & & & & $\begin{array}{l}-0.020 \\
(0.024)\end{array}$ \\
\hline male & $\begin{array}{l}0.058 \\
(0.091)\end{array}$ & $\begin{array}{l}0.060 \\
(0.093)\end{array}$ & $\begin{array}{l}0.062 \\
(0.094)\end{array}$ & $\begin{array}{l}0.062 \\
(0.094)\end{array}$ & $\begin{array}{l}0.067 \\
(0.094)\end{array}$ \\
\hline age & $\begin{array}{l}0.050 \\
(0.018) * * *\end{array}$ & $\begin{array}{l}0.044 \\
(0.019)^{* *}\end{array}$ & $\begin{array}{l}0.044 \\
(0.019)^{* *}\end{array}$ & $\begin{array}{l}0.044 \\
(0.019) * *\end{array}$ & $\begin{array}{l}0.043 \\
(0.019)^{* *}\end{array}$ \\
\hline age squared & $\begin{array}{l}-0.001 \\
(0.000)^{* * *}\end{array}$ & $\begin{array}{l}-0.001 \\
(0.000)^{* *}\end{array}$ & $\begin{array}{l}-0.001 \\
(0.000)^{* *}\end{array}$ & $\begin{array}{l}-0.001 \\
(0.000)^{* *}\end{array}$ & $\begin{array}{l}-0.001 \\
(0.000)^{* *}\end{array}$ \\
\hline Nicaragua & $\begin{array}{l}0.188 \\
(0.132)\end{array}$ & $\begin{array}{l}0.218 \\
(0.135)\end{array}$ & $\begin{array}{l}0.211 \\
(0.137)\end{array}$ & $\begin{array}{l}0.210 \\
(0.137)\end{array}$ & $\begin{array}{l}0.202 \\
(0.136)\end{array}$ \\
\hline El Salvador & $\begin{array}{l}0.137 \\
(0.175)\end{array}$ & $\begin{array}{l}0.155 \\
(0.178)\end{array}$ & $\begin{array}{l}0.150 \\
(0.179)\end{array}$ & $\begin{array}{l}0.151 \\
(0.179)\end{array}$ & $\begin{array}{l}0.152 \\
(0.180)\end{array}$ \\
\hline year $=2003$ & $\begin{array}{l}-0.176 \\
(0.124)\end{array}$ & $\begin{array}{l}-0.158 \\
(0.128)\end{array}$ & $\begin{array}{l}-0.155 \\
(0.129)\end{array}$ & $\begin{array}{l}-0.154 \\
(0.129)\end{array}$ & $\begin{array}{l}-0.144 \\
(0.129)\end{array}$ \\
\hline year $=2004$ & $\begin{array}{l}-0.253 \\
(0.214)\end{array}$ & $\begin{array}{l}-0.257 \\
(0.218)\end{array}$ & $\begin{array}{l}-0.247 \\
(0.221)\end{array}$ & $\begin{array}{l}-0.241 \\
(0.220)\end{array}$ & $\begin{array}{l}-0.213 \\
(0.218)\end{array}$ \\
\hline year $=2005$ & $\begin{array}{l}-0.472 \\
(0.172)^{* * *}\end{array}$ & $\begin{array}{l}-0.447 \\
(0.176)^{* *}\end{array}$ & $\begin{array}{l}-0.441 \\
(0.177)^{* *}\end{array}$ & $\begin{array}{l}-0.436 \\
(0.177)^{* *}\end{array}$ & $\begin{array}{l}-0.412 \\
(0.176)^{* *}\end{array}$ \\
\hline Constant & $\begin{array}{l}-0.185 \\
(0.438) \\
\end{array}$ & $\begin{array}{l}0.000 \\
(0.460) \\
\end{array}$ & $\begin{array}{l}0.037 \\
(0.473) \\
\end{array}$ & $\begin{array}{l}0.163 \\
(0.458) \\
\end{array}$ & $\begin{array}{l}0.110 \\
(0.479) \\
\end{array}$ \\
\hline Observations & 109 & 108 & 108 & 108 & 108 \\
\hline R-squared & 0.32 & 0.32 & 0.32 & 0.32 & 0.32 \\
\hline
\end{tabular}

Notes: Standard errors in parentheses; * significant at 10\%; ** significant at 5\%; *** significant at $1 \%$; omitted country is Guatemala, omitted year is 2002 .

Figure 14: The effect of winning the business plan competition on business launch or expansion 


\begin{tabular}{|c|c|c|c|c|c|c|c|c|}
\hline \multirow[t]{2}{*}{ Dependent variable } & \multicolumn{4}{|c|}{$=1$ if new business launched } & \multicolumn{4}{|c|}{$=1$ if existing business expanded } \\
\hline & $(1)$ & (2) & $\begin{array}{l}\text { treatment } \\
\text { varies with } \\
\text { score, IV } \\
\text { (3) }\end{array}$ & $\begin{array}{l}\text { include } \\
\log (\text { prize }), \\
\text { IV } \\
(4)\end{array}$ & $(5)$ & $(6)$ & $\begin{array}{l}\text { treatment } \\
\text { varies with } \\
\text { score, IV } \\
\text { (7) }\end{array}$ & $\begin{array}{l}\text { include } \\
\log \text { (prize), } \\
\text { IV } \\
(8)\end{array}$ \\
\hline winner $(\mathrm{W})$ & $\begin{array}{l}0.339 \\
(0.126) * * *\end{array}$ & $\begin{array}{l}0.168 \\
(0.228)\end{array}$ & $\begin{array}{l}0.239 \\
(0.247)\end{array}$ & & $\begin{array}{l}0.184 \\
(0.124)\end{array}$ & $\begin{array}{l}0.122 \\
(0.180)\end{array}$ & $\begin{array}{l}0.176 \\
(0.223)\end{array}$ & \\
\hline S3 & & $\begin{array}{l}0.077 \\
(0.158)\end{array}$ & $\begin{array}{l}-0.181 \\
(0.367)\end{array}$ & $\begin{array}{l}0.159 \\
(0.189)\end{array}$ & & $\begin{array}{l}0.024 \\
(0.120)\end{array}$ & $\begin{array}{l}-0.056 \\
(0.226)\end{array}$ & $\begin{array}{l}0.056 \\
(0.145)\end{array}$ \\
\hline S3 squared & & $\begin{array}{l}-0.025 \\
(0.067)\end{array}$ & $\begin{array}{l}-0.127 \\
(0.147)\end{array}$ & $\begin{array}{l}-0.121 \\
(0.147)\end{array}$ & & $\begin{array}{l}-0.002 \\
(0.030)\end{array}$ & $\begin{array}{l}-0.020 \\
(0.054)\end{array}$ & $\begin{array}{l}-0.021 \\
(0.054)\end{array}$ \\
\hline W_S3 & & & $\begin{array}{l}0.455 \\
(0.585)\end{array}$ & & & & $\begin{array}{l}0.150 \\
(0.359)\end{array}$ & \\
\hline $\log ($ prizemoney $)$ & & & & $\begin{array}{l}0.024 \\
(0.026)\end{array}$ & & & & $\begin{array}{l}0.019 \\
(0.024)\end{array}$ \\
\hline $\log ($ prizemoney $) * S 3$ & & & & $\begin{array}{l}0.047 \\
(0.063)\end{array}$ & & & & $\begin{array}{l}0.017 \\
(0.039)\end{array}$ \\
\hline male & $\begin{array}{l}0.044 \\
(0.128)\end{array}$ & $\begin{array}{l}0.052 \\
(0.128)\end{array}$ & $\begin{array}{l}0.038 \\
(0.130)\end{array}$ & $\begin{array}{l}0.039 \\
(0.130)\end{array}$ & $\begin{array}{l}0.073 \\
(0.147)\end{array}$ & $\begin{array}{l}0.034 \\
(0.157)\end{array}$ & $\begin{array}{l}0.043 \\
(0.160)\end{array}$ & $\begin{array}{l}0.044 \\
(0.160)\end{array}$ \\
\hline age & $\begin{array}{l}0.036 \\
(0.023)\end{array}$ & $\begin{array}{l}0.032 \\
(0.024)\end{array}$ & $\begin{array}{l}0.034 \\
(0.024)\end{array}$ & $\begin{array}{l}0.034 \\
(0.024)\end{array}$ & $\begin{array}{l}0.053 \\
(0.040)\end{array}$ & $\begin{array}{l}0.025 \\
(0.046)\end{array}$ & $\begin{array}{l}0.027 \\
(0.047)\end{array}$ & $\begin{array}{l}0.027 \\
(0.047)\end{array}$ \\
\hline age squared & $\begin{array}{l}-0.000 \\
(0.000)^{*}\end{array}$ & $\begin{array}{l}-0.000 \\
(0.000)\end{array}$ & $\begin{array}{l}-0.000 \\
(0.000)\end{array}$ & $\begin{array}{l}-0.000 \\
(0.000)\end{array}$ & $\begin{array}{l}-0.001 \\
(0.001)\end{array}$ & $\begin{array}{l}-0.000 \\
(0.001)\end{array}$ & $\begin{array}{l}-0.000 \\
(0.001)\end{array}$ & $\begin{array}{l}-0.000 \\
(0.001)\end{array}$ \\
\hline Nicaragua & $\begin{array}{l}0.171 \\
(0.204)\end{array}$ & $\begin{array}{l}0.195 \\
(0.206)\end{array}$ & $\begin{array}{l}0.197 \\
(0.207)\end{array}$ & $\begin{array}{l}0.195 \\
(0.207)\end{array}$ & $\begin{array}{l}-0.043 \\
(0.180)\end{array}$ & $\begin{array}{l}-0.032 \\
(0.198)\end{array}$ & $\begin{array}{l}0.001 \\
(0.215)\end{array}$ & $\begin{array}{l}0.002 \\
(0.215)\end{array}$ \\
\hline El Salvador & $\begin{array}{l}0.714 \\
(0.179) * * *\end{array}$ & $\begin{array}{l}0.682 \\
(0.181) * * *\end{array}$ & $\begin{array}{l}0.696 \\
(0.183) * * *\end{array}$ & $\begin{array}{l}0.689 \\
(0.182)^{* * *}\end{array}$ & $\begin{array}{l}-0.606 \\
(0.277)^{* *}\end{array}$ & $\begin{array}{l}-0.705 \\
(0.304)^{* *}\end{array}$ & $\begin{array}{l}-0.666 \\
(0.322)^{* *}\end{array}$ & $\begin{array}{l}-0.662 \\
(0.322)^{* *}\end{array}$ \\
\hline year $=2003$ & $\begin{array}{l}-0.304 \\
(0.159)^{*}\end{array}$ & $\begin{array}{l}-0.285 \\
(0.161)^{*}\end{array}$ & $\begin{array}{l}-0.281 \\
(0.162)^{*}\end{array}$ & $\begin{array}{l}-0.279 \\
(0.162)^{*}\end{array}$ & $\begin{array}{l}0.015 \\
(0.188)\end{array}$ & $\begin{array}{l}0.043 \\
(0.210)\end{array}$ & $\begin{array}{l}0.024 \\
(0.217)\end{array}$ & $\begin{array}{l}0.023 \\
(0.217)\end{array}$ \\
\hline year $=2004$ & $\begin{array}{l}0.329 \\
(0.214)\end{array}$ & $\begin{array}{l}0.277 \\
(0.219)\end{array}$ & $\begin{array}{l}0.269 \\
(0.220)\end{array}$ & $\begin{array}{l}0.267 \\
(0.220)\end{array}$ & $\begin{array}{l}-0.671 \\
(0.318) * *\end{array}$ & $\begin{array}{l}-0.767 \\
(0.331)^{* *}\end{array}$ & $\begin{array}{l}-0.785 \\
(0.338) * *\end{array}$ & $\begin{array}{l}-0.783 \\
(0.337)^{* *}\end{array}$ \\
\hline year $=2005$ & $\begin{array}{l}0.000 \\
(0.000)\end{array}$ & $\begin{array}{l}0.000 \\
(0.000)\end{array}$ & $\begin{array}{l}0.000 \\
(0.000)\end{array}$ & $\begin{array}{l}0.000 \\
(0.000)\end{array}$ & $\begin{array}{l}-0.916 \\
(0.287) * * *\end{array}$ & $\begin{array}{l}-0.974 \\
(0.299) * * *\end{array}$ & $\begin{array}{l}-0.977 \\
(0.302) * * *\end{array}$ & $\begin{array}{l}-0.974 \\
(0.302)^{* * *}\end{array}$ \\
\hline Constant & -0.462 & -0.236 & -0.384 & -0.204 & 0.587 & 1.287 & 1.160 & 1.289 \\
\hline & $(0.498)$ & $(0.549)$ & $(0.583)$ & $(0.533)$ & $(0.858)$ & $(1.007)$ & $(1.063)$ & $(1.029)$ \\
\hline Observations & 57 & 57 & 57 & 57 & 46 & 45 & 45 & 45 \\
\hline R-squared & 0.37 & 0.40 & 0.41 & 0.41 & 0.50 & 0.49 & 0.49 & 0.49 \\
\hline
\end{tabular}

Notes: Standard errors in parentheses; * significant at 10\%; ** significant at 5\%; *** significant at 1\%; omitted country is Guatemala, omitted year is 2002 .

Figure 15: The effect of winning the business plan competition on business launch or expansion, separate regressions 


\subsection{Robustness to treating El Salvador separately}

As pointed out before, the pooling of all business plan competitions may not be appropriate. El Salvador in particular presents a special case. In El Salvador, TechnoServe puts participants through UNCTAD's Empretec program, whereas in the other countries the training is entirely conducted by TechnoServe. In addition, as we have seen before, the discontinuity in the El Salvador competition is slightly less pronounced than for the other competitions. For both of these reasons, we investigate the robustness of the results to excluding El Salvador from the analysis, as well as to treating El Salvador separately, both by estimating the key regressions separately for El Salvador, and by interacting the training variables with an El Salvador indicator variable. The results are in tables 16, 17 and 18.

We find some indication that the training workshops in El Salvador are different than training workshops in the other two countries, Guatemala and Nicaragua. Regarding the effect of the full training program, we find that the point estimates for the training indicator variable are quite different (although the statistical difference is only borderline), and in column 3 of table 16 we find that the treatment effect is significantly different (at the 10\% level) in El Salvador than in the other countries, when we restrict all other variables to have the same effects across countries. The differences in the other two stages are not statistically significant, but the negative point estimates suggest that the effect of the business plan competition might be stronger in El Salvador than in the other countries in the first training stage, and weaker than in other two countries in the second training stage and at the winner stage. 


\begin{tabular}{|c|c|c|c|c|}
\hline \multicolumn{5}{|c|}{ Dependent variable $=1$ if new business launched or existing business expanded } \\
\hline & exclude El Salvador & only El Salvador & $\begin{array}{l}\text { treatment varies with El } \\
\text { Salvador } \\
\text { (3) }\end{array}$ & $\begin{array}{l}\text { treatment varies with El } \\
\text { Salvador (including } \\
\text { interaction with score } \\
\text { S1) } \\
\text { (4) }\end{array}$ \\
\hline received training $(\mathrm{T})$ & $\begin{array}{l}0.144 \\
(0.074)^{*}\end{array}$ & $\begin{array}{l}0.371 \\
(0.153) * *\end{array}$ & $\begin{array}{l}0.137 \\
(0.069) * *\end{array}$ & $\begin{array}{l}0.142 \\
(0.073)^{*}\end{array}$ \\
\hline $\mathrm{T}^{*}$ El Salvador & & & $\begin{array}{l}0.219 \\
(0.113)^{*}\end{array}$ & $\begin{array}{l}0.207 \\
(0.128)\end{array}$ \\
\hline $\mathrm{T} * \mathrm{~S} 1 * \mathrm{E} 1$ Salvador & & & & $\begin{array}{l}0.013 \\
(0.064)\end{array}$ \\
\hline $\mathrm{T} * \mathrm{~S} 1$ & $\begin{array}{l}0.195 \\
(0.181)\end{array}$ & $\begin{array}{l}-0.001 \\
(0.287)\end{array}$ & $\begin{array}{l}0.116 \\
(0.148)\end{array}$ & $\begin{array}{l}0.109 \\
(0.150)\end{array}$ \\
\hline S1 (phase 1 score) & $\begin{array}{l}-0.068 \\
(0.098)\end{array}$ & $\begin{array}{l}0.034 \\
(0.183)\end{array}$ & $\begin{array}{l}-0.026 \\
(0.083)\end{array}$ & $\begin{array}{l}-0.026 \\
(0.083)\end{array}$ \\
\hline S1 squared & $\begin{array}{l}-0.030 \\
(0.032)\end{array}$ & $\begin{array}{l}0.011 \\
(0.043)\end{array}$ & $\begin{array}{l}-0.013 \\
(0.026)\end{array}$ & $\begin{array}{l}-0.013 \\
(0.026)\end{array}$ \\
\hline male & $\begin{array}{l}-0.002 \\
(0.054)\end{array}$ & $\begin{array}{l}-0.002 \\
(0.070)\end{array}$ & $\begin{array}{l}-0.002 \\
(0.042)\end{array}$ & $\begin{array}{l}-0.001 \\
(0.042)\end{array}$ \\
\hline age & $\begin{array}{l}0.028 \\
(0.013)^{* *}\end{array}$ & $\begin{array}{l}0.036 \\
(0.016)^{* *}\end{array}$ & $\begin{array}{l}0.033 \\
(0.010)^{* * *}\end{array}$ & $\begin{array}{l}0.033 \\
(0.010)^{* * *}\end{array}$ \\
\hline age squared & $\begin{array}{l}-0.000 \\
(0.000)^{*}\end{array}$ & $\begin{array}{l}-0.000 \\
(0.000)^{* *}\end{array}$ & $\begin{array}{l}-0.000 \\
(0.000)^{* * *}\end{array}$ & $\begin{array}{l}-0.000 \\
(0.000)^{* * *}\end{array}$ \\
\hline Nicaragua & $\begin{array}{l}0.023 \\
(0.064)\end{array}$ & & $\begin{array}{l}0.019 \\
(0.063)\end{array}$ & $\begin{array}{l}0.020 \\
(0.064)\end{array}$ \\
\hline El Salvador & & & $\begin{array}{l}-0.021 \\
(0.102)\end{array}$ & $\begin{array}{l}-0.017 \\
(0.104)\end{array}$ \\
\hline year $=2003$ & $\begin{array}{l}0.000 \\
(0.000)\end{array}$ & $\begin{array}{l}0.074 \\
(0.073)\end{array}$ & $\begin{array}{l}0.070 \\
(0.072)\end{array}$ & $\begin{array}{l}0.071 \\
(0.072)\end{array}$ \\
\hline year $=2004$ & $\begin{array}{l}0.000 \\
(0.000)\end{array}$ & $\begin{array}{l}0.000 \\
(0.000)\end{array}$ & $\begin{array}{l}0.218 \\
(0.122)^{*}\end{array}$ & $\begin{array}{l}0.221 \\
(0.123)^{*}\end{array}$ \\
\hline year $=2005$ & $\begin{array}{l}-0.198 \\
(0.075)^{* * *}\end{array}$ & $\begin{array}{l}0.015 \\
(0.105)\end{array}$ & $\begin{array}{l}0.017 \\
(0.097)\end{array}$ & $\begin{array}{l}0.020 \\
(0.098)\end{array}$ \\
\hline Constant & $\begin{array}{l}-0.193 \\
(0.272)\end{array}$ & $\begin{array}{l}-0.555 \\
(0.349) \\
\end{array}$ & $\begin{array}{l}-0.466 \\
(0.233)^{* *}\end{array}$ & $\begin{array}{l}-0.471 \\
(0.235)^{* *}\end{array}$ \\
\hline Observations & 395 & 260 & 655 & 655 \\
\hline R-squared & 0.11 & 0.17 & 0.17 & 0.17 \\
\hline
\end{tabular}

Figure 16: The effect of training on business launch or expansion: Robustness to changes in the treatment of El Salvador 


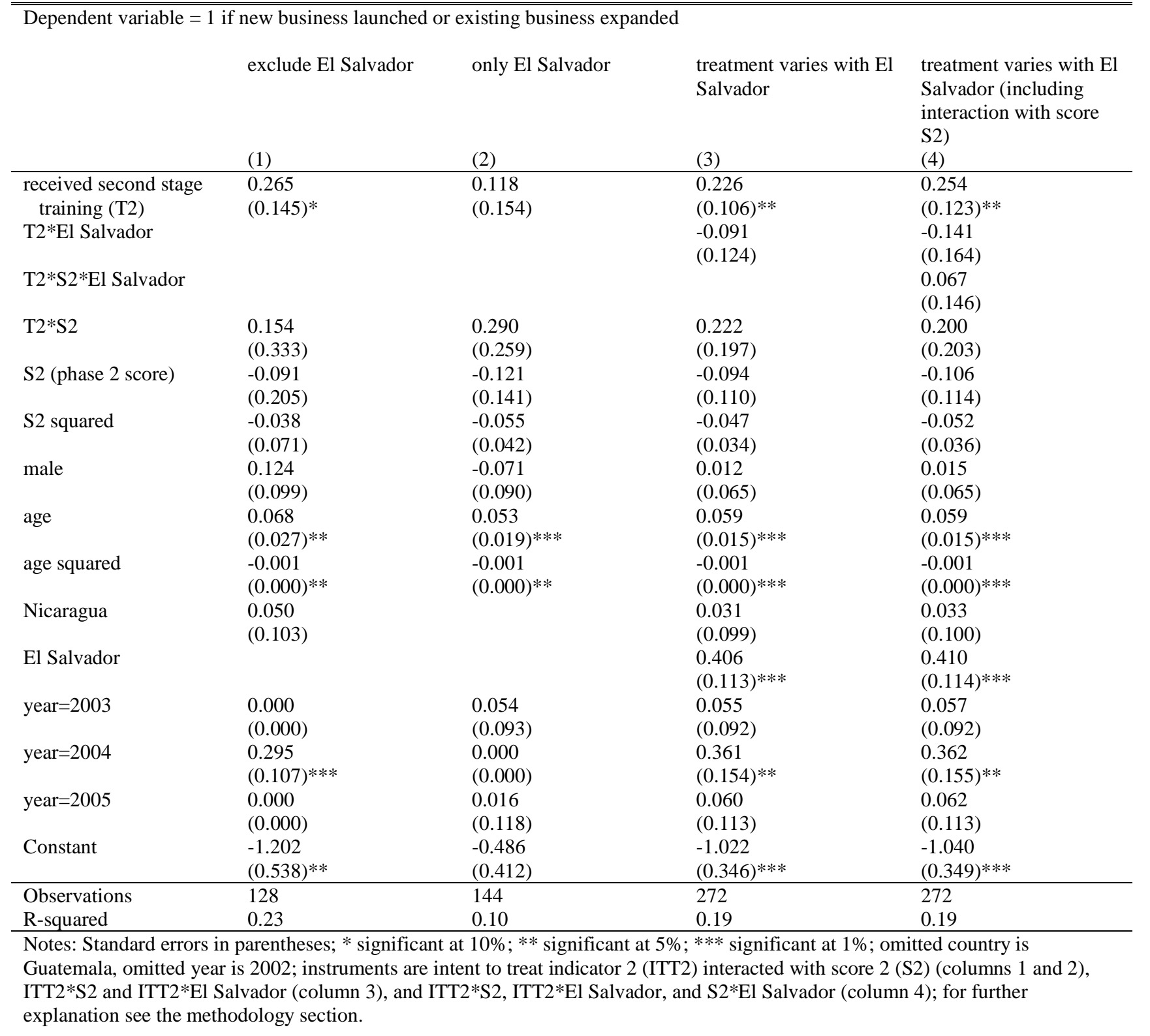

Figure 17: The effect of the second stage of training on business launch or expansion: Robustness to changes in the treatment of El Salvador 


\begin{tabular}{|c|c|c|c|c|}
\hline \multicolumn{5}{|c|}{ Dependent variable $=1$ if new business launched or existing business expanded } \\
\hline & exclude El Salvador & only El Salvador & $\begin{array}{l}\text { treatment varies with El } \\
\text { Salvador }\end{array}$ & $\begin{array}{l}\text { treatment varies with El } \\
\text { Salvador (including } \\
\text { interaction with score } \\
\text { S3) } \\
\text { (4) }\end{array}$ \\
\hline \multirow[t]{2}{*}{ winner $(\mathrm{W})$} & 0.277 & 0.194 & 0.211 & 0.192 \\
\hline & $(0.273)$ & $(0.201)$ & $(0.176)$ & $(0.178)$ \\
\hline \multirow[t]{2}{*}{$\mathrm{W}^{*}$ El Salvador } & & & -0.085 & -0.022 \\
\hline & & & $(0.184)$ & $(0.205)$ \\
\hline \multirow[t]{2}{*}{$\mathrm{W} * \mathrm{~S} 3 * \mathrm{E} 1$ Salvador } & & & & -0.261 \\
\hline & & & & $(0.372)$ \\
\hline \multirow{2}{*}{$\mathrm{W} * \mathrm{~S} 3$} & 0.356 & -0.325 & -0.102 & -0.043 \\
\hline & $(0.674)$ & $(0.385)$ & $(0.270)$ & $(0.283)$ \\
\hline \multirow[t]{2}{*}{ S3 (phase 3 score) } & -0.108 & 0.149 & 0.138 & 0.135 \\
\hline & $(0.432)$ & $(0.186)$ & $(0.165)$ & $(0.165)$ \\
\hline \multirow{2}{*}{ S3 squared } & -0.082 & 0.037 & 0.025 & 0.023 \\
\hline & $(0.167)$ & $(0.050)$ & $(0.048)$ & $(0.048)$ \\
\hline \multirow[t]{2}{*}{ male } & 0.045 & 0.065 & 0.066 & 0.069 \\
\hline & $(0.159)$ & $(0.118)$ & $(0.095)$ & $(0.095)$ \\
\hline \multirow[t]{2}{*}{ age } & 0.030 & 0.055 & 0.043 & 0.044 \\
\hline & $(0.045)$ & $(0.022)^{* *}$ & $(0.019)^{* *}$ & $(0.019)^{* *}$ \\
\hline \multirow[t]{2}{*}{ age squared } & -0.000 & -0.001 & -0.001 & -0.001 \\
\hline & $(0.001)$ & $(0.000)^{* *}$ & $(0.000)^{* *}$ & $(0.000)^{* *}$ \\
\hline \multirow[t]{2}{*}{ Nicaragua } & 0.244 & & 0.222 & 0.231 \\
\hline & $(0.159)$ & & $(0.139)$ & $(0.140)$ \\
\hline \multirow[t]{2}{*}{ El Salvador } & & & 0.182 & 0.179 \\
\hline & & & $(0.193)$ & $(0.193)$ \\
\hline \multirow[t]{2}{*}{ year $=2003$} & 0.000 & -0.157 & -0.156 & -0.153 \\
\hline & $(0.000)$ & $(0.120)$ & $(0.129)$ & $(0.130)$ \\
\hline \multirow[t]{2}{*}{ year $=2004$} & 0.162 & 0.000 & -0.253 & -0.267 \\
\hline & $(0.152)$ & $(0.000)$ & $(0.222)$ & $(0.223)$ \\
\hline \multirow[t]{2}{*}{ year $=2005$} & 0.000 & -0.432 & -0.439 & -0.448 \\
\hline & $(0.000)$ & $(0.170)^{* *}$ & $(0.178)^{* *}$ & $(0.179)^{* *}$ \\
\hline \multirow[t]{2}{*}{ Constant } & -0.228 & -0.095 & 0.024 & 0.025 \\
\hline & $(0.884)$ & $(0.496)$ & $(0.476)$ & $(0.477)$ \\
\hline Observations & 54 & 54 & 108 & 108 \\
\hline R-squared & 0.28 & 0.38 & 0.32 & 0.33 \\
\hline
\end{tabular}

Figure 18: The effect of winning the business plan competition on business launch or expansion: Robustness to changes in the treatment of El Salvador 


\subsection{The role of gender}

Empirical work as well as policy makers' decisions suggest that the effects of the program may vary by gender. In particular, in the policy world, micro finance organizations often target women, partly based on the idea that women may have less access to credit. On the other hand, recent empirical work by de Mel et al. (2007b) suggests that there may be differences in the returns to capital between male and female entrepreneurs.

In this section we therefore study whether treatment effects of the training program vary by the participant's gender. To this end, we interact the treatment indicator variables for the various stages of the business plan competition (training of first stage, training of second stage and winning) with the indicator variable that is one if an individual is male, and zero otherwise.

The results indicate that the effect of the full training program on business start-up or expansion is larger for male participants. In table 19 we see that in 5 of the 6 specifications shown in that table the coefficient on the trained*male interaction term is positive, and this coefficient is statistically significant in the last specification.

Looking at tables 20 and 21 then shows that the more positive effect of training on males seems to be mainly due to difference in the effect of the first stage of training: In table 20 we no longer see a consistent picture of the $\mathrm{T} 2 *$ male interaction term, which flips between positive and negative signs, none of them significant.

In table 21 the winner*male interaction term is now negative throughout, with coefficients being statistically significant in the specifications that pool both outcomes of interest, i.e. where the dependent variable is 1 if a business either expanded or was newly established. Thus, we find a significantly larger effect for starting-up/expanding a business for women in the winning stage. ${ }^{15}$ Looking at the magnitudes of the point estimates of the interaction terms in columns 3 to 6 indicates that the effect seems to be driven by a larger effect of winning on start-up, rather than an effect on expansion of businesses.

Overall, the findings in this sub-section are consistent with the hypothesis that women are more constrained than men to come up with funding for business start-up or expansions.

\footnotetext{
${ }^{15}$ In results that are not shown, we find that the difference in the magnitude of the coefficients is even larger if we run the regression separately, thus allowing all coefficients to vary. However, because the number of observations is reduced by running regressions separately, results are less precise and the coefficients not statistically different.
} 


\begin{tabular}{|c|c|c|c|c|c|c|}
\hline $\begin{array}{l}\text { Dependent } \\
\text { variable }=1 \text { if }\end{array}$ & $\begin{array}{l}\text { launch or } \\
\text { expand }\end{array}$ & $\begin{array}{l}\text { launch or } \\
\text { expand } \\
\text { treatment varies } \\
\text { with score } \\
\text { (2) }\end{array}$ & launch & $\begin{array}{l}\text { launch } \\
\text { treatment varies } \\
\text { with score } \\
\text { (4) }\end{array}$ & expand & $\begin{array}{l}\text { expand } \\
\text { treatment varies } \\
\text { with score } \\
\text { (6) }\end{array}$ \\
\hline \multirow[t]{2}{*}{ received training } & 0.196 & 0.100 & 0.037 & -0.012 & 0.172 & -0.089 \\
\hline & $(0.094) * *$ & $(0.124)$ & $(0.107)$ & $(0.120)$ & $(0.130)$ & $(0.170)$ \\
\hline \multirow[t]{2}{*}{ trained $*$ male } & -0.002 & 0.150 & 0.075 & 0.171 & 0.118 & 0.495 \\
\hline & $(0.088)$ & $(0.144)$ & $(0.100)$ & $(0.124)$ & $(0.126)$ & $(0.202)^{* *}$ \\
\hline \multirow[t]{2}{*}{$\mathrm{T} * \mathrm{~S} 1$} & & 0.247 & & 0.302 & & 0.062 \\
\hline & & $(0.174)$ & & $(0.194)$ & & $(0.241)$ \\
\hline \multirow[t]{2}{*}{$\mathrm{T} * \mathrm{~S} 1 *$ male } & & -0.105 & & -0.129 & & 0.243 \\
\hline & & $(0.109)$ & & $(0.089)$ & & $(0.166)$ \\
\hline \multirow[t]{2}{*}{$\mathrm{S} 1 *$ male } & & -0.030 & & & & -0.341 \\
\hline & & $(0.086)$ & & & & $(0.144)^{* *}$ \\
\hline \multirow[t]{2}{*}{ S1 } & 0.036 & -0.038 & 0.035 & -0.075 & 0.013 & 0.132 \\
\hline & $(0.026)$ & $(0.105)$ & $(0.030)$ & $(0.101)$ & $(0.038)$ & $(0.148)$ \\
\hline \multirow[t]{2}{*}{ S1 squared } & 0.006 & -0.025 & -0.001 & -0.035 & 0.008 & -0.037 \\
\hline & $(0.009)$ & $(0.026)$ & $(0.010)$ & $(0.031)$ & $(0.013)$ & $(0.037)$ \\
\hline \multirow[t]{2}{*}{ male } & 0.001 & -0.034 & -0.027 & -0.025 & -0.122 & -0.419 \\
\hline & $(0.066)$ & $(0.113)$ & $(0.073)$ & $(0.073)$ & $(0.098)$ & $(0.161)^{* * *}$ \\
\hline \multirow[t]{2}{*}{ all-female program } & 0.081 & 0.102 & 0.034 & 0.117 & -0.140 & -0.206 \\
\hline & $(0.134)$ & $(0.136)$ & $(0.200)$ & $(0.210)$ & $(0.232)$ & $(0.236)$ \\
\hline \multirow[t]{2}{*}{ age } & 0.032 & 0.032 & 0.024 & 0.024 & -0.008 & -0.008 \\
\hline & $(0.010)^{* * *}$ & $(0.010)^{* * *}$ & $(0.011)^{* *}$ & $(0.011)^{* *}$ & $(0.016)$ & $(0.016)$ \\
\hline \multirow[t]{2}{*}{ age squared } & -0.000 & -0.000 & -0.000 & -0.000 & 0.000 & 0.000 \\
\hline & $(0.000)^{* * *}$ & $(0.000)^{* * *}$ & $(0.000)^{* *}$ & $(0.000)^{* *}$ & $(0.000)$ & $(0.000)$ \\
\hline \multirow[t]{2}{*}{ Nicaragua } & -0.020 & -0.000 & -0.034 & -0.008 & -0.044 & -0.028 \\
\hline & $(0.061)$ & $(0.063)$ & $(0.072)$ & $(0.074)$ & $(0.085)$ & $(0.087)$ \\
\hline \multirow[t]{2}{*}{ El Salvador } & 0.026 & 0.049 & -0.125 & -0.129 & -0.435 & -0.388 \\
\hline & $(0.107)$ & (0.109) & $(0.150)$ & $(0.150)$ & $(0.211)^{* *}$ & $(0.216)^{*}$ \\
\hline \multirow[t]{2}{*}{ year $=2003$} & 0.039 & 0.054 & -0.113 & -0.094 & -0.051 & -0.032 \\
\hline & $(0.071)$ & $(0.072)$ & $(0.076)$ & $(0.077)$ & $(0.126)$ & $(0.126)$ \\
\hline \multirow[t]{2}{*}{ year $=2004$} & 0.098 & 0.115 & -0.208 & -0.215 & -0.381 & -0.353 \\
\hline & $(0.140)$ & $(0.141)$ & $(0.185)$ & $(0.186)$ & $(0.251)$ & $(0.251)$ \\
\hline \multirow[t]{2}{*}{ year $=2005$} & -0.098 & -0.069 & -0.343 & -0.331 & -0.724 & -0.688 \\
\hline & $(0.119)$ & $(0.120)$ & $(0.165)^{* *}$ & $(0.165)^{* *}$ & $(0.232)^{* * *}$ & $(0.233)^{* * *}$ \\
\hline \multirow[t]{2}{*}{ Constant } & -0.320 & -0.368 & 0.063 & -0.017 & 1.397 & 1.506 \\
\hline & $(0.235)$ & $(0.256)$ & $(0.278)$ & $(0.286)$ & $(0.400)^{* * *}$ & $(0.418)^{* * *}$ \\
\hline Observations & 655 & 655 & 392 & 392 & 249 & 249 \\
\hline R-squared & 0.16 & 0.16 & 0.13 & 0.13 & 0.35 & 0.37 \\
\hline
\end{tabular}

Figure 19: The effect of training on business launch or expansion: the interaction with gender 


\begin{tabular}{|c|c|c|c|c|c|c|}
\hline $\begin{array}{l}\text { Dependent } \\
\text { variable }=1 \text { if }\end{array}$ & $\begin{array}{l}\text { launch or } \\
\text { expand } \\
\text { (1) }\end{array}$ & $\begin{array}{l}\text { launch or } \\
\text { expand } \\
\text { treatment varies } \\
\text { with score } \\
\text { (2) }\end{array}$ & launch & $\begin{array}{l}\text { launch } \\
\text { treatment varies } \\
\text { with score } \\
\text { (4) }\end{array}$ & expand & $\begin{array}{l}\text { expand } \\
\text { treatment varies } \\
\text { with score } \\
\text { (6) }\end{array}$ \\
\hline $\mathrm{T} 2$ & $\begin{array}{l}0.104 \\
(0.131)\end{array}$ & $\begin{array}{l}0.253 \\
(0.193)\end{array}$ & $\begin{array}{l}0.467 \\
(0.211)^{* *}\end{array}$ & $\begin{array}{l}0.589 \\
(0.286) * *\end{array}$ & $\begin{array}{l}-0.016 \\
(0.168)\end{array}$ & $\begin{array}{l}0.235 \\
(0.265)\end{array}$ \\
\hline $\mathrm{T} 2 *$ male & $\begin{array}{l}0.131 \\
(0.129)\end{array}$ & $\begin{array}{l}-0.054 \\
(0.227)\end{array}$ & $\begin{array}{l}0.009 \\
(0.182)\end{array}$ & $\begin{array}{l}-0.129 \\
(0.336)\end{array}$ & $\begin{array}{l}0.127 \\
(0.162)\end{array}$ & $\begin{array}{l}-0.184 \\
(0.290)\end{array}$ \\
\hline $\mathrm{T} 2 * \mathrm{~S} 2$ & & $\begin{array}{l}0.209 \\
(0.197)\end{array}$ & & $\begin{array}{l}0.424 \\
(0.294)\end{array}$ & & $\begin{array}{l}-0.078 \\
(0.225)\end{array}$ \\
\hline $\mathrm{S} 2 *$ male & & $\begin{array}{l}0.088 \\
(0.097)\end{array}$ & & $\begin{array}{l}0.045 \\
(0.148)\end{array}$ & & $\begin{array}{l}0.191 \\
(0.141)\end{array}$ \\
\hline S2 & $\begin{array}{l}0.005 \\
(0.041)\end{array}$ & $\begin{array}{l}-0.168 \\
(0.131)\end{array}$ & $\begin{array}{l}-0.040 \\
(0.068)\end{array}$ & $\begin{array}{l}-0.293 \\
(0.189)\end{array}$ & $\begin{array}{l}-0.025 \\
(0.048)\end{array}$ & $\begin{array}{l}-0.154 \\
(0.169)\end{array}$ \\
\hline $\mathrm{S} 2$ squared & $\begin{array}{l}-0.011 \\
(0.014)\end{array}$ & $\begin{array}{l}-0.043 \\
(0.035)\end{array}$ & $\begin{array}{l}-0.018 \\
(0.023)\end{array}$ & $\begin{array}{l}-0.089 \\
(0.059)\end{array}$ & $\begin{array}{l}0.005 \\
(0.015)\end{array}$ & $\begin{array}{l}0.015 \\
(0.036)\end{array}$ \\
\hline male & $\begin{array}{l}-0.022 \\
(0.085)\end{array}$ & $\begin{array}{l}0.083 \\
(0.137)\end{array}$ & $\begin{array}{l}0.043 \\
(0.113)\end{array}$ & $\begin{array}{l}0.129 \\
(0.204)\end{array}$ & $\begin{array}{l}-0.035 \\
(0.108)\end{array}$ & $\begin{array}{l}0.164 \\
(0.184)\end{array}$ \\
\hline age & $\begin{array}{l}0.058 \\
(0.015) * * *\end{array}$ & $\begin{array}{l}0.059 \\
(0.015)^{* * *}\end{array}$ & $\begin{array}{l}0.027 \\
(0.019)\end{array}$ & $\begin{array}{l}0.030 \\
(0.020)\end{array}$ & $\begin{array}{l}0.016 \\
(0.021)\end{array}$ & $\begin{array}{l}0.021 \\
(0.022)\end{array}$ \\
\hline age squared & $\begin{array}{l}-0.001 \\
(0.000)^{* * * *}\end{array}$ & $\begin{array}{l}-0.001 \\
(0.000) * * *\end{array}$ & $\begin{array}{l}-0.000 \\
(0.000)\end{array}$ & $\begin{array}{l}-0.000 \\
(0.000)^{*}\end{array}$ & $\begin{array}{l}-0.000 \\
(0.000)\end{array}$ & $\begin{array}{l}-0.000 \\
(0.000)\end{array}$ \\
\hline all-female program & $\begin{array}{l}0.210 \\
(0.167)\end{array}$ & $\begin{array}{l}0.199 \\
(0.168)\end{array}$ & $\begin{array}{l}0.259 \\
(0.517)\end{array}$ & $\begin{array}{l}0.269 \\
(0.521)\end{array}$ & $\begin{array}{l}-0.114 \\
(0.215)\end{array}$ & $\begin{array}{l}-0.118 \\
(0.215)\end{array}$ \\
\hline Nicaragua & $\begin{array}{l}0.043 \\
(0.098)\end{array}$ & $\begin{array}{l}0.046 \\
(0.098)\end{array}$ & $\begin{array}{l}-0.016 \\
(0.133)\end{array}$ & $\begin{array}{l}-0.005 \\
(0.134)\end{array}$ & $\begin{array}{l}-0.002 \\
(0.115)\end{array}$ & $\begin{array}{l}-0.006 \\
(0.115)\end{array}$ \\
\hline El Salvador & $\begin{array}{l}0.266 \\
(0.138)^{*}\end{array}$ & $\begin{array}{l}0.283 \\
(0.139)^{* *}\end{array}$ & $\begin{array}{l}-0.013 \\
(0.460)\end{array}$ & $\begin{array}{l}-0.017 \\
(0.464)\end{array}$ & $\begin{array}{l}-0.402 \\
(0.187) * *\end{array}$ & $\begin{array}{l}-0.393 \\
(0.188)^{* *}\end{array}$ \\
\hline year $=2003$ & $\begin{array}{l}0.038 \\
(0.091)\end{array}$ & $\begin{array}{l}0.051 \\
(0.092)\end{array}$ & $\begin{array}{l}-0.196 \\
(0.108)^{*}\end{array}$ & $\begin{array}{l}-0.161 \\
(0.111)\end{array}$ & $\begin{array}{l}0.012 \\
(0.146)\end{array}$ & $\begin{array}{l}0.005 \\
(0.146)\end{array}$ \\
\hline year $=2004$ & $\begin{array}{l}0.232 \\
(0.177)\end{array}$ & $\begin{array}{l}0.259 \\
(0.178)\end{array}$ & $\begin{array}{l}-0.120 \\
(0.481)\end{array}$ & $\begin{array}{l}-0.115 \\
(0.484)\end{array}$ & $\begin{array}{l}-0.384 \\
(0.249)\end{array}$ & $\begin{array}{l}-0.357 \\
(0.250)\end{array}$ \\
\hline year $=2005$ & $\begin{array}{l}-0.054 \\
(0.142)\end{array}$ & $\begin{array}{l}-0.039 \\
(0.142)\end{array}$ & $\begin{array}{l}-0.402 \\
(0.460)\end{array}$ & $\begin{array}{l}-0.396 \\
(0.463)\end{array}$ & $\begin{array}{l}-0.738 \\
(0.217) * * *\end{array}$ & $\begin{array}{l}-0.734 \\
(0.218) * * *\end{array}$ \\
\hline Constant & $\begin{array}{l}-0.805 \\
(0.347)^{* *}\end{array}$ & $\begin{array}{l}-0.981 \\
(0.369)^{* * *}\end{array}$ & $\begin{array}{l}-0.033 \\
(0.639)\end{array}$ & $\begin{array}{l}-0.276 \\
(0.664)\end{array}$ & $\begin{array}{l}1.048 \\
(0.506) * *\end{array}$ & $\begin{array}{l}0.784 \\
(0.551)\end{array}$ \\
\hline Observations & 272 & 272 & 150 & 150 & 108 & 108 \\
\hline R-squared & 0.19 & 0.20 & 0.26 & 0.27 & 0.47 & 0.48 \\
\hline
\end{tabular}

Figure 20: The effect of the second stage of training on business launch or expansion: the interaction with gender 


\begin{tabular}{|c|c|c|c|c|c|c|}
\hline $\begin{array}{l}\text { Dependent } \\
\text { variable }=1 \text { if }\end{array}$ & $\begin{array}{l}\text { launch or } \\
\text { expand }\end{array}$ & $\begin{array}{l}\text { launch or } \\
\text { expand } \\
\text { treatment } \\
\text { varies with } \\
\text { score } \\
\text { (2) }\end{array}$ & launch & $\begin{array}{l}\text { launch } \\
\text { treatment } \\
\text { varies with } \\
\text { score } \\
\text { (4) }\end{array}$ & expand & $\begin{array}{l}\text { expand } \\
\text { treatment } \\
\text { varies with } \\
\text { score } \\
(6) \\
\end{array}$ \\
\hline Winner (W) & $\begin{array}{l}0.557 \\
(0.160) * * *\end{array}$ & $\begin{array}{l}0.430 \\
(0.183) * *\end{array}$ & $\begin{array}{l}0.546 \\
(0.325)\end{array}$ & $\begin{array}{l}0.386 \\
(0.350)\end{array}$ & $\begin{array}{l}0.316 \\
(0.208)\end{array}$ & $\begin{array}{l}0.213 \\
(0.248)\end{array}$ \\
\hline Winner*male & $\begin{array}{l}-0.318 \\
(0.184)^{*}\end{array}$ & $\begin{array}{l}-0.353 \\
(0.188)^{*}\end{array}$ & $\begin{array}{l}-0.244 \\
(0.353)\end{array}$ & $\begin{array}{l}-0.300 \\
(0.363)\end{array}$ & $\begin{array}{l}-0.191 \\
(0.240)\end{array}$ & $\begin{array}{l}-0.137 \\
(0.255)\end{array}$ \\
\hline $\mathrm{S} 3$ & & $\begin{array}{l}0.112 \\
(0.090)\end{array}$ & & $\begin{array}{l}0.108 \\
(0.163)\end{array}$ & & $\begin{array}{l}0.026 \\
(0.121)\end{array}$ \\
\hline S3 squared & & $\begin{array}{l}0.015 \\
(0.028)\end{array}$ & & $\begin{array}{l}-0.014 \\
(0.068)\end{array}$ & & $\begin{array}{l}-0.004 \\
(0.031)\end{array}$ \\
\hline male & $\begin{array}{l}0.169 \\
(0.103)\end{array}$ & $\begin{array}{l}0.184 \\
(0.107)^{*}\end{array}$ & $\begin{array}{l}0.083 \\
(0.140)\end{array}$ & $\begin{array}{l}0.099 \\
(0.141)\end{array}$ & $\begin{array}{l}0.164 \\
(0.187)\end{array}$ & $\begin{array}{l}0.108 \\
(0.209)\end{array}$ \\
\hline all-female program & $\begin{array}{l}0.508 \\
(0.262)^{*}\end{array}$ & $\begin{array}{l}0.487 \\
(0.264)^{*}\end{array}$ & $\begin{array}{l}0.000 \\
(0.000)\end{array}$ & $\begin{array}{l}0.000 \\
(0.000)\end{array}$ & $\begin{array}{l}0.000 \\
(0.000)\end{array}$ & $\begin{array}{l}0.000 \\
(0.000)\end{array}$ \\
\hline age & $\begin{array}{l}0.052 \\
(0.018)^{* * *}\end{array}$ & $\begin{array}{l}0.046 \\
(0.019) * *\end{array}$ & $\begin{array}{l}0.038 \\
(0.024)\end{array}$ & $\begin{array}{l}0.034 \\
(0.024)\end{array}$ & $\begin{array}{l}0.048 \\
(0.040)\end{array}$ & $\begin{array}{l}0.021 \\
(0.047)\end{array}$ \\
\hline age squared & $\begin{array}{l}-0.001 \\
(0.000)^{* * *}\end{array}$ & $\begin{array}{l}-0.001 \\
(0.000)^{* *}\end{array}$ & $\begin{array}{l}-0.001 \\
(0.000)^{*}\end{array}$ & $\begin{array}{l}-0.000 \\
(0.000)\end{array}$ & $\begin{array}{l}-0.001 \\
(0.001)\end{array}$ & $\begin{array}{l}-0.000 \\
(0.001)\end{array}$ \\
\hline Nicaragua & $\begin{array}{l}0.171 \\
(0.130)\end{array}$ & $\begin{array}{l}0.198 \\
(0.132)\end{array}$ & $\begin{array}{l}0.192 \\
(0.207)\end{array}$ & $\begin{array}{l}0.216 \\
(0.208)\end{array}$ & $\begin{array}{l}-0.072 \\
(0.184)\end{array}$ & $\begin{array}{l}-0.052 \\
(0.204)\end{array}$ \\
\hline El Salvador & $\begin{array}{l}-0.158 \\
(0.220)\end{array}$ & $\begin{array}{l}-0.124 \\
(0.223)\end{array}$ & $\begin{array}{l}0.710 \\
(0.180)^{* * * *}\end{array}$ & $\begin{array}{l}0.675 \\
(0.182) * * *\end{array}$ & $\begin{array}{l}-0.618 \\
(0.279)^{* *}\end{array}$ & $\begin{array}{l}-0.707 \\
(0.308)^{* *}\end{array}$ \\
\hline year $=2003$ & $\begin{array}{l}-0.152 \\
(0.122)\end{array}$ & $\begin{array}{l}-0.127 \\
(0.126)\end{array}$ & $\begin{array}{l}-0.279 \\
(0.164)^{*}\end{array}$ & $\begin{array}{l}-0.257 \\
(0.165)\end{array}$ & $\begin{array}{l}0.028 \\
(0.189)\end{array}$ & $\begin{array}{l}0.062 \\
(0.215)\end{array}$ \\
\hline year $=2004$ & $\begin{array}{l}-0.522 \\
(0.251)^{* *}\end{array}$ & $\begin{array}{l}-0.505 \\
(0.254)^{* *}\end{array}$ & $\begin{array}{l}0.323 \\
(0.215)\end{array}$ & $\begin{array}{l}0.263 \\
(0.220)\end{array}$ & $\begin{array}{l}-0.638 \\
(0.322)^{*}\end{array}$ & $\begin{array}{l}-0.733 \\
(0.341)^{* *}\end{array}$ \\
\hline year $=2005$ & $\begin{array}{l}-0.744 \\
(0.217)^{* * *}\end{array}$ & $\begin{array}{l}-0.699 \\
(0.221)^{* * *}\end{array}$ & $\begin{array}{l}0.000 \\
(0.000)\end{array}$ & $\begin{array}{l}0.000 \\
(0.000)\end{array}$ & $\begin{array}{l}-0.876 \\
(0.293) * * *\end{array}$ & $\begin{array}{l}-0.936 \\
(0.310)^{* * *}\end{array}$ \\
\hline Constant & $\begin{array}{l}-0.004 \\
(0.441) \\
\end{array}$ & $\begin{array}{l}0.176 \\
(0.460) \\
\end{array}$ & $\begin{array}{l}-0.551 \\
(0.517) \\
\end{array}$ & $\begin{array}{l}-0.304 \\
(0.557) \\
\end{array}$ & $\begin{array}{l}0.598 \\
(0.862) \\
\end{array}$ & $\begin{array}{l}1.292 \\
(1.018) \\
\end{array}$ \\
\hline Observations & 109 & 108 & 57 & 57 & 46 & 45 \\
\hline R-squared & 0.36 & 0.36 & 0.38 & 0.41 & 0.51 & 0.50 \\
\hline
\end{tabular}

Figure 21: The effect of winning on business launch or expansion: the effect of gender 


\section{Conclusion}

We investigate whether training and business development programs in developing countries can help improve entrepreneurial skills and foster entrepreneurial activities such as the creation and expansion of businesses, which at the micro-level is of immediate relevance for the livelihoods of individuals and at the macro-level essential for long-term growth. From a theoretical point of view, our study is related to work on entrepreneurship in diverse areas of economics such as economic growth, finance, and industrial organization in which entrepreneurial skills are often taken as exogenous. From a policy point of view, the present paper helps to fill a gap because programs such as the one that we study are widespread around the developing world but their impact is not well understood.

We exploit a quasi-experimental setup in the program under study to estimate the causal impact of this particular training and business development program using data from three Central American countries. Our findings indicate that overall the program is successful in inducing the creation of new businesses and the expansion of existing businesses. Our baseline parameter estimates imply a 9 to 11 percentage points higher probability of opening a business (for individuals without a business before the start of the program) in the treatment group and a 23 to 26 percentage points higher probability of expanding a business (for individuals with an existing business before the program) in the group of treated entrepreneurs. However, the findings suggest that not all parts of the program are equally successful, and we also find differential impacts of different parts of the program on the start-up of new business and the expansion of existing businesses. In addition, exploiting the fact that in the last stage the most successful participants of the program (the "winners") receive substantial monetary prizes we find some evidence for financial constraints. The findings further indicate that financial constraints are more important for women who wish to start or expand a business than for men. Dissecting the program further and understanding which components of the program cause the behavioral changes that we observe will be the focus of future research.

\section{References}

[1] Baumol, William (1968): Entrepreneurship in Economic Theory. American Economic Review, Papers and Proceedings 58 (2) 64-71.

[2] de Mel, Suresh, David McKenzie and Christopher Woodruff (2006): Returns to capital in microenterprises: evidence from a field experiment. Manuscript. 
[3] de Mel, Suresh, David McKenzie and Christopher Woodruff (2007a): Measuring Microenterprise Profits: Must We Ask How the Sausage Is Made?. Manuscript.

[4] de Mel, Suresh, David McKenzie and Christopher Woodruff (2007b): Who does Microfinance Fail to Reach? Experimental Evidence on Gender and Microenterprise Returns. Manuscript.

[5] Djankov, Simeon, Edward Miguel, Yingyi Qian, Gérard Roland, and Ekaterina Zhuravskaya (2005): Who are Russia's Entrepreneurs? Journal of the European Economic Association, 3 (2-3) 587-597.

[6] Djankov, Simeon, Yingyi Qian, Gérard Roland, and Ekaterina Zhuravskaya (2006): Who are China's Entrepreneurs? AER Papers and Proceedings 96(2) 348-352.

[7] Foster, Andrew and Mark Rosenzweig (1995): Learning by Doing and Learning from Others: Human Capital and Technical Change in Agriculture. Journal of Political Economy 103 (6) 1176-1209.

[8] Greenstone, Michael and Enrico Moretti (2004): Bidding for Industrial Plants: Does Winning a 'Million Dollar Plant' Increase Welfare? Manuscript, MIT.

[9] Hausman, Ricardo and Dani Rodrik (2003): Economic development as Self-Discovery, Journal of. Development Economics, Vol. 72, No.2, pp. 603-633

[10] Hidalgo, Cesar, Bailey Klinger, Albert-László Barabási, and Ricardo Hausmann (2007): The Product Space Conditions the Development of Nations. Science 317(5837) 482-487.

[11] Jacob, Brian and Lars Lefgren (2004): Remedial Education and Student Achievement: A Regression-Discontinuity Analysis Review of Economics and Statistics 86 (1) 226-244.

[12] Jovanovich, Boyan (1982): Selection and the evolution of industry, Econometrica 50, 649-670.

[13] Karlan, Dean and Martin Valdivia (2006): Teaching Entrepreneurship: Impact of Business Training on Microfinance Clients and Institutions. Yale University Economic Growth Center Discussion Paper No 941.

[14] Leibenstein , Harvey (1987): Entrepreneurship, Entrepreneurial Training, and XEfficiency Theory. Journal of Economic Behavior \& Organization 8 (2) 191-205. 
[15] Ludwig, Jens and Douglas Miller (2007): Does Head Start Improve Children's Life Chances? Evidence from a Regression Discontinuity Design. Quarterly Journal of Economics 122 (1) 159-208.

[16] McKenzie, David and Chris Woodruff (2004): Do Entry Costs Provide an Empirical Basis for Poverty Traps? Evidence from Mexican Microenterprises. Economic Development and Cultural Change, 55(1): 3-42.

[17] Schumpeter, Joseph (1911): Theorie der Wirtschaftlichen Entwicklung. Duncker \& Humblot, Leipzig.

[18] Schündeln, Matthias (2006): Modeling Firm Dynamics to Identify the Cost of Financing Constraints in Ghanaian Manufacturing. Manuscript.

[19] Schündeln, Matthias (2007): Financing Constraints: A New Test and an Application to Developing Countries. Manuscript.

[20] van der Klaauw, Wilbert, Jinyong Hahn and Petra Todd (2001): Identification and Estimation of Treatment Effects with a Regression-Discontinuity Design. Econometrica, 69(1), 201-209.

[21] van der Klaauw, Wilbert (2002): Estimating the Effect of Financial Aid Offers on College Enrollment: A Regression-Discontinuity Approach. International Economic Review, 43 (4) 1249-1287.

\section{Appendix}

\section{A Content of the business training program}

This appendix provides a more detailed description of the content of TechnoServe's "business plan competitions". This appendix draws heavily on material from TechnoServe.

Phase 1 Interested (potential) entrepreneurs submit applications. These are scored to identify promising applicants. A fixed number of individuals are admitted to the program, which determines a cutoff, and individuals with scores above the cutoff are allowed to enroll in the training program. 
Phase 2 The training program in the business plan competitions is meant to provide participants with all of the tools and knowledge necessary to take their business idea and compose a complete and detailed business plan. It is organized around the key sections of a business plan, with a class-based lecture with theory and examples, along with some limited break-out discussion among participants. This process forces the participant to consider all of the facets of their business, such as production, finance, marketing, sales, and logistics, in a systematic way. The process in layers, with each successive layer providing greater detail on the previous one. The first layer consists of two units, the second layer of three units, and the third layer of six units.

The first unit is the business description, in which participants will have to describe the business in general terms, compose the firm's mission and vision statements, define the firm's goals, and perform a structured analysis of strengths, weaknesses, opportunities, and threats related to the business idea. Examples from other businesses are presented. The second unit covers the description of the business concept. Its goal is to teach participants to define the concept in terms of how it satisfies market needs, instead of defining the concept from the business owner's own point of view.

The next three units cover industry analysis, market analysis, and descriptions of the product/service. These are meant to dig one level deeper in their description of the business concept. In the section on industry analysis, participants are taught how to define industries in terms of employment and value added, as well as market trends. The trainers also discuss describing the industry in terms of geographic and temporal production patterns, and finally suggest possible sources of data in the country of the competition, such as relevant government agency websites, industry association websites, and general information sources. The unit on market analysis describes how one can precisely identify potential target markets through segmentation by geography, demographics, incomes, and so on, and then evaluate the potential of each market segment to determine the most suitable ones to target. The unit on description of the product or service is meant to re-orient participants' conceptualization of their product to that of the customer rather than producer by encouraging them to describe it in terms of its principal functions, characteristics, and uses to consumers.

The base layer of the business plan training consists of six units: competitors, marketing plan, sales projections, operations, organization and administration, and financial projections. In the competitors unit, the trainers teach participants the dimensions on which they need to characterize the competition and compare it to their own capabilities. They are also taught about the importance of barriers to entry for future competitors. The market plan module 
attempts to cover issues such as how to differentiate a product/service, how to set prices, and talks about creating and protecting brand names, distribution chains, and general marketing strategies such as advertising campaigns, strategic alliances, and free samples. The sales projection unit suggests how to make monthly sales projections, including sources of estimates, and how to then plug them into the financial projections. The operations module includes lectures on lean production, standardization of inputs, employment options, quality control, and inventory control. The organization and administration unit teaches participants how to make organizational charts and job descriptions, as well as design organizations around customer service. The final and longest module is on financial projections, including investment estimates, operational cost estimates, financing requirements (including potential sources of investment), financial statements (balance sheet, income statement, and cash flow statement), and finally overall profit/loss projections.

In addition to these topics, there are also lectures on general entrepreneurial attitudes and orientation, as well as country-specific information on starting a business, such as the relevant government departments and programs, different legal forms, and potential sources of capital.

At the conclusion of this phase, participants have been presented all of the components of a business plan. Their draft business plans are judged, and those with the top phase 2 scores continue to phase 3 .

Phase 3 In phase 3, participants are given detailed feedback in order to revise and improve their business plan. They are also given one-on-one time with consultants to help refine their business plan. At the conclusion of this phase, they have a longer and more detailed business plan that has benefited from review and advice by both consultants and the judges. These plans are scored, and the top ones win the financial prize.

Timing In the case of El Salvador, the training consists of the 7 day UNCTAD EMPRETEC course, followed by two four-hour sessions by TechnoServe on how to compose a business plan using the methodology described above. The participants then have approximately 8 weeks before the business plans are due. In the case of Nicaragua and Guatemala, there is no EMPRETEC training, and instead the classes based on the business plan methodology described above are done in more detail. They are divided up into approximately three full-day sessions, one per weekend. The participants have approximately one month to then compose and turn in their business plans. For all competitions, the plans advancing to phase 3 are revised over a period of 1-2 weeks. 